NBER WORKING PAPER SERIES

\title{
LABOR SUPPLY RESPONSE TO THE EARNED INCOME TAX CREDIT
}

Nada Eissa

Jeffrey B. Liebman

Working Paper No. 5158

\author{
NATIONAL BUREAU OF ECONOMIC RESEARCH \\ 1050 Massachusetts Avenue \\ Cambridge, MA 02138 \\ June 1995
}

We are grateful to Gary Chamberlain, David Cutler, Doug Elmendorf, Dan Feenberg, Martin Feldstein, Judy Hellerstein, Jim Hines, Guido Imbens, Larry Katz, Brigitte Madrian, Marian Vaillant and seminar participants at Harvard, MIT and UC Berkeley for useful suggestions. We thank John Coder for his assistance with the CPS-IMF match. All errors are our own. Liebman was supported in part by a National Science Foundation Graduate Research Fellowship. This paper is part of NBER's research program in Public Economics. Any opinions, findings, conclusions or recommendations expressed in this paper are those of the authors and do not necessarily reflect the views of the National Science Foundation or the National Bureau of Economic Research.

() 1995 by Nada Eissa and Jeffrey B. Liebman. All rights reserved. Short sections of text, not to exceed two paragraphs, may be quoted without explicit permission provided that full credit, including (- notice, is given to the source. 


\title{
LABOR SUPPLY RESPONSE TO THE EARNED INCOME TAX CREDIT
}

\begin{abstract}
In a series of major expansions starting in 1987, the earned income tax credit (EITC) has become a central part of the federal government's anti-poverty strategy. In this paper, we examine the impact of the Tax Reform Act of 1986 (TRA86), which included an expansion of the EITC, on labor force participation and hours of work. The expansion of the credit affected an easily identifiable group, single women with children, but is predicted to have had no effect on another group, single women without children. Other features of TRA86, such as the increase in the value of dependent exemptions and the large increase in the standard deduction for head of household filers, are predicted by economic theory to have reinforced the impact of the EITC on the relative labor supply outcomes of single women with and without children. We therefore compare the change in labor supply of single women with children to the change in labor supply of single women without children.

We find that between 1984-1986 and 1988-1989 single women with children increased their labor force participation by 1.4 percentage points (from a base of 73.1 percent) relative to single women without children. We explore a number of possible explanations for this finding and conclude that the 1987 expansion of the EITC and the other provisions of TRA86 are the most likely explanations. We find no effect of the EITC expansion on the hours of work of single women with children who were already in the labor force. Compared to other elements of the welfare system, the EITC appears to produce little distortion of work incentives.
\end{abstract}

Nada Eissa

Department of Economics

Evans Hall, Room 521

University of California, Berkeley

Berkeley, CA 94720

and NBER
Jeffrey B. Liebman

Department of Economics

Harvard University

Cambridge, MA 02138 
Historically, the United States has chosen to provide a safety net for families with children. Since 1935, Aid to Families with Dependent Children (AFDC) has supplied cash welfare payments to needy single-parent families. Families on AFDC may also receive food stamps, medicaid, and housing assistance. Because the maximum level of benefits is received by families with no income and because benefits are reduced almost dollar for dollar with additional earnings ${ }^{1}$, the welfare system is predicted by static labor supply theory to discourage the labor force participation and hours of work of single parents. Existing empirical evidence mostly confirms these theoretical predictions. ${ }^{2}$

In a series of major expansions beginning in 1987, the earned income tax credit (EITC) has emerged as a popular alternative method for transferring income to needy families with children. The EITC is a refundable credit; therefore any credit due in excess of tax liability is refunded to the taxpayer in the form of a tax refund check. In 1996, when the most recent expansion of the EITC is fully phased in, the maximum credit will reach $\$ 2206$ for a taxpayer with one child and $\$ 3644$ for a taxpayer with two or more children. Advocates of the EITC argue that the credit transfers income to a particularly deserving group of people, the working poor, and that the redistribution occurs with much less distortion to labor supply than is caused by other elements of the welfare system. In particular, the credit is said to encourage labor force participation.

The EITC creates a complicated and ambiguous set of labor supply incentives. Standard labor supply theory does indeed predict that the EITC will encourage labor force participation. This occurs because the EITC is available only to taxpayers with earned income. But theory also predicts that the credit reduces the number of hours worked by most eligible taxpayers already in the labor force. While the credit initially increases with income, producing offsetting income and substitution effects on hours

\footnotetext{
' For discussions of effective marginal tax rates from the welfare and tax systems see Fraker et al. (1985), Dickert et al. (1994), and Giannarelli and Steurle (1994).

2 Moffitt (1992) and Danziger et al (1981) survey the empirical literature. Moffitt writes, "the available evidence unequivocally shows that the AFDC program generates nontrivial work disincentives." (p. 16).
} 
worked, over seventy percent of recipients have incomes in regions in which the credit is constant (and therefore produces only a negative income effect on labor supply) or is being phased-out (producing negative income and substitution effects). ${ }^{3}$ Moreover, since the phase-out of the credit produces a nonconvexity in the budget constraint, taxpayers with incomes beyond the phase-out region may choose to reduce their hours of work and take advantage of the credit. In fact, cumulative marginal tax rates can be quite high in the phase-out region. In 1996, a taxpayer with two children and income between $\$ 11,900$ to $\$ 29,200$ faces a net marginal tax rate (on the worker's marginal revenue product) of 53 percent. $^{4}$

In this paper, we examine the impact of the Tax Reform Act of 1986 (TRA86), which included an expansion of the EITC, on labor force participation and hours of work. The expansion of the credit affects an easily identifiable group, single women with children, but is predicted to have no effect on another group, single women without children. Other features of TRA86, such as the increase in the value of dependent exemptions and the large increase in the standard deduction for head of household filers, are predicted by economic theory to have reinforced the impact of the EITC on the relative labor supply outcomes of single women with and without children. We therefore compare the change in labor supply of single women with children to the change in labor supply of single women without children. We find that after TRA86, the labor force participation of single women with children increased by 1.4 percentage points relative to single women without children (from a base of 73.1 percent). We explore

\footnotetext{
${ }^{3}$ In the 1990 SOI tax return sample, 52.6 percent of EITC recipients are in the phase-out region, 20.8 percent are in the constant region and 25.9 percent are in the phase-in region. A few have incomes above or below the EITC limits.

${ }^{4}$ We assume that the full incidence of payroll taxes falls on the worker. The net marginal tax rate is the share of the worker's marginal revenue product which is paid in taxes and lost benefits. A worker whose gross pay is $\$ 10$ an hour would have a marginal revenue product of $\$ 10.765$, since the employer pays half of the OASDHI payroll tax. After subtracting $\$ 1.50$ for federal income tax, $\$ .60$ for state income tax, $\$ .765$ for the employee's share of OASDHI, and \$2.106 in lost EITC payments, the taxpayer has a net of tax and benefits hourly wage of $\$ 5.029$. Dividing the total tax and lost benefits $\$ 5.736$ by $\$ 10.765$ yields a marginal tax rate of 53.3 percent. If some of employee compensation is in untaxed benefits then this is an overstatement of marginal tax rates.
} 
a number of alternative explanations for this finding, and conclude that the expansion of the EITC and the other provisions of TRA86 are the most likely explanation. We find no effect of the EITC expansion on the hours of work of single women with children who were already in the labor force. ${ }^{5}$

The remainder of the paper is divided into eleven sections. Section I explains the eligibility rules and the structure of the EITC and describes the effectiveness of the EITC in raising the disposable incomes of households with children. Section II uses simple static labor supply theory to generate predictions of the impact of the EITC on participation and hours of work. Section III discusses our identification strategy and our various treatment and control groups. Section IV describes the data. Section V presents basic participation results. Section VI explains the regression framework which we rely on for the rest of the paper. Section VII presents regression results of the impact of the TRA86 on labor force participation. Section VIII explores alternative explanations for our findings. Section IX presents estimates of the impact of the EITC on hours of work. Section X discusses our combined results on participation and hours. Finally, section XI concludes.

\section{THE EITC AND THE INCOMES OF FAMILIES WITH CHILDREN}

\section{How the EITC Works}

The earned income tax credit began in 1975 as a modest program aimed at offsetting the social security payroll tax for low income families with children. After major expansions in the tax acts of 1986, 1990, and 1993, the EITC has become a central part of the federal government's anti-poverty strategy. By 1996, federal spending on the EITC (including both tax expenditures and outlays) is

\footnotetext{
${ }^{5}$ A number of earlier papers have analyzed labor supply response to the EITC. However, we believe that our paper is the first that estimates actual behavioral responses to a change in the credit. Three papers have used estimates from the negative income tax experiments to predict the impact of the EITC on labor supply (Hoffman and Seidman, 1990; GAO, 1993; and Holtzblatt et al., 1994). In addition, Dickert et al. (1994) estimates a joint labor market and welfare participation model that incorporates the EITC. Using their results and hours of work elasticities from the labor supply literature, they simulate the effects on labor supply of the recent expansion of the EITC.
} 
projected to be 1.7 times as large as federal spending on AFDC. ${ }^{6}$

A taxpayer currently needs to meet three requirements in order to be eligible for the earned income tax credit. First, the taxpayer must have positive earned income. Earned income is the sum of wage and salary income, business self-employment income, and farm self-employment income. ${ }^{7}$ Second, a taxpayer's adjusted gross income and earned income must both be below a specified amount (In 1996, the maximum income for a taxpayer with two or more children to be eligible to receive the EITC is $\$ 29,200$ ). Third, a taxpayer must have a qualifying child. ${ }^{8}$ A qualifying child is a child, grandchild, stepchild, or foster child of the taxpayer who is under the age of 19 (under 24 if a full-time student) or permanently disabled, and who lived with the taxpayer for more than one-half of the tax year. ${ }^{9}$ Until 1991, the rules for EITC eligibility were more complicated and depended on the taxpayer's filing status. ${ }^{10}$ The credit is refundable so that a taxpayer with no federal tax liability, for example, would receive a tax refund from the government for the full amount of the credit. Taxpayers may also receive the credit

${ }^{6}$ Committee on Ways and Means (1994), pp. 389 and 704. In 1996, the EITC is projected to cost $\$ 25.1$ billion; federal expenditures on AFDC are expected to be $\$ 14.8$ billion; and state expenditures on AFDC are projected to be $\$ 12.4$ billion.

${ }^{7}$ Earned income also includes union strike benefits, long-term disability benefits received prior to minimum retirement age, and some nontaxable income such as voluntary salary deferrals for $401(\mathrm{k})$ plans, combat zone pay, and housing allowances received by members of the clergy.

${ }^{8}$ Beginning in 1994 , a small credit is available to low-income workers without children.

${ }^{9}$ A married child cannot be a qualifying child unless the taxpayer claims the child as a dependent. Foster children may only be qualifying children if they reside with the taxpayer for the entire year. A taxpayer who is a qualifying child for another taxpayer may not claim the EITC. If a child is a qualifying child for more than one taxpayer (a parent and grandparent for example), then only the taxpayer with the highest AGI is entitled to claim the qualifying child.

${ }^{10}$ Before 1991, a taxpayer who was married was eligible for the EITC if he or she filed jointly, claimed a dependent child on his or her tax return, and the child lived with the taxpayer for more than six months during the year. The children of taxpayers filing as household heads or surviving spouses did not have to meet the six month residency test. An unmarried taxpayer filing as head of household did not have to claim the child as a dependent in order to be eligible for the EITC, but, in order to file as head of household (and be eligible for the EITC), the taxpayer must have paid more than half the cost of keeping up the home. Therefore both married filers (through the rules for claiming a dependent) and head of household filers were required to meet a support test. AFDC payments are not considered support provided by the taxpayer. Therefore, a taxpayer with $\$ 6000$ in AFDC income and $\$ 5000$ in earned income was not eligible for the EITC under pre-1991 rules. 
throughout the year with their paychecks; but in 1989, the most recent year for which data are available, less than one-half of one percent of all EITC recipients availed themselves of this early payment option."

The amount of the credit to which a taxpayer is entitled depends on the taxpayer's earned income, adjusted gross income, and, since 1991, the number of EITC-eligible children in the household. In 1996, the credit for a family with two or more children is phased in at a 40 percent rate over the first $\$ 9110$ of earned income, resulting in a maximum credit of $\$ 3644$. As income rises from $\$ 9110$ to $\$ 11,900$ of income, the credit remains at $\$ 3644$. Then the credit is phased-out at a 21.06 percent rate on income starting from $\$ 11,900$ (the maximum of AGI and earned income governs the phase-out), so that by $\$ 29,203$ the taxpayer is no longer eligible for the credit. $^{12}$

The Impact of the EITC on Disposable Income

In providing an earnings subsidy of as much as 40 percent, the EITC has a large impact on household income for many of its recipients. Table I presents projections for 1996 of average household disposable income and the composition of that income for families with children. The projections are based upon an exact match of the March 1991 CPS to tax return data from the IRS's Individual Master File for tax year $1990 .^{13}$ The data were aged to 1996 by assuming that all components of income grew at the same rate as the CPI between 1990 and 1994, and at 4 percent thereafter. We impute EITC benefit amounts using the 1996 rules.

In table I, we divide households into those with one adult (part I) and those with more than one adult (part II). We further divide households based on whether any individual in the household filed a tax

$"$ GAO (1992).

12 These credit amounts assume an annual inflation rate of 4 percent between 1994 and 1996.

${ }^{13}$ All work with the matched data set was performed by Census Bureau employees. Further details about the CPS-IRS match are available in Liebman (1995). 
return, and if a tax return was filed, on whether the tax return claimed the EITC. Finally, if at least one tax return filed by a member of the household claimed the EITC, we separate households by which EITC region the tax return was in. ${ }^{14}$

The first row of table I (part I) shows that the population of one-adult households with children totals 6.73 million. Of these households, almost one-third (two million households) do not file tax returns. Only 36 percent of these non-filing households have non-zero earnings (column 3), so most of them would be ineligible for the EITC even if they filed tax returns. Another one-third file tax returns, but do not receive the EITC, either because they lack qualifying children or because they have excessive income or lack positive earnings.

Table I also shows that 2.45 million one-adult households containing 4.59 million children are predicted to receive the EITC in 1996. The average disposable income (not including the EITC) for these families is $\$ 16,399$ (in 1996 dollars). According to the CPS, most income for these households is earned income, although more than one-third receive AFDC, food stamps, or SSI, and two-thirds have other sources of income such as interest, dividends, or pensions. Federal income and payroll taxes reduce total income for these households by roughly ten percent. On average, the EITC adds $\$ 1733$, or 10.6 percent of disposable income, to the incomes of these households with taxpayers filing returns claiming the credit.

\footnotetext{
${ }^{14}$ The tax return data in the 1990 IMF do not indicate whether or not the taxpayer claimed the EITC. However, it is possible to do an extremely accurate job of predicting EITC recipiency from data available in the IMF. When we apply our prediction methodology to the 1990 SOI tax file which includes the IMF variables as well as EITC recipiency, our predicted sample of EITC returns contains 94 percent of actual EITC recipients and only 5 percent of our predicted sample are non-recipients. Applying the methodology to 1991, when the support test no longer applied, generates almost identical results. Nonetheless, we only predict that 10.2 million households will receive the EITC in 1996. In comparison, the Joint Committee on Taxation predicts that over 14 million taxpayers with children will receive the EITC in 1996. Even after adjusting for households with multiple EITC recipients, our sample substantially under-predicts 1996 EITC recipients. Part of the discrepancy arises because we do not increase the number of returns filed between 1990 and 1996 for population growth. However, even when we apply 1990 EITC rules to our sample, we are still about 15 percent below the actual number of 1990 EITC recipients. This presumably occurs because some CPS adults fail to match to their tax returns because they did not supply a social security number on their tax returns or reported different social security numbers on their tax returns from those they gave to the CPS (we used a simple hot deck procedure to allocate tax returns to taxpayers who did not give a social security number to the CPS). In addition, it is possible that the CPS undercounts low-income families with children (see Scholz 1990).
} 
The EITC is particularly important for recipients in the phase-in and constant regions where it boosts disposable income by 14.2 percent and 21.1 percent respectively. However, these households are only 40 percent of total recipients. The rest are in the phase-out region, where the impact of the EITC on income is smaller ( 8.1 percent).

Part II of Table I presents data on households with children and two or more adults. We predict that more than 7.7 million such households will receive the EITC in 1996 (three-fourths of the total number of recipient households). The EITC plays a much smaller role in increasing the disposable incomes of these households. On average, the EITC raises household disposable income by $\$ 1882$ or only 6.1 percent. The main reason the EITC has less of an impact on these households is that CPS earned income for these households is much higher than the income reported on the tax return claiming the EITC. For example, in the phase-in region (defined as income between $\$ 0$ and $\$ 9110$ ), average CPS household income is $\$ 21,717$. This occurs because many of these households file more than one tax return. Even in the households that file only one return, CPS income is often higher than the income on the tax return because it is often the case that there is an adult in the household who does not file a tax return and whose income is not reported on the tax return that is filed. Of course, these households are on average larger than one-adult households, so their higher incomes do not necessarily imply that they are less needy.

\section{STATIC LABOR SUPPLY THEORY AND THE EITC}

In the most basic static labor supply theory, a taxpayer facing a fixed wage chooses how many hours to work in order to maximize his or her utility over leisure and after-tax income. Figure 1 shows how the introduction of an EITC shifts the budget constraint of an otherwise untaxed individual from ADE to $\mathrm{ABCDE}$. Under the new budget constraint, every choice of hours (or equivalently pre-tax earnings) produces at least as much after-tax earnings (and utility) as it did before the earned income tax credit was 
introduced. The well-being of a taxpayer who does not work has not changed because no earned income tax credit is available to a taxpayer with zero earnings. Thus any taxpayer who preferred working before will still prefer working, and some taxpayers may find that the additional after-tax income from the EITC makes it worth entering the labor force. The impact of the EITC on the labor force participation of unmarried taxpayers is therefore unambiguously positive. ${ }^{15}$

The impact of introducing an EITC on the hours of work of a taxpayer already participating depends on which region of the EITC the taxpayer was in before the credit was introduced. For a worker in the phase-in, the effect on labor supply is theoretically ambiguous: the credit subsidizes the worker's wage so that the substitution effect encourages additional hours while the income effect causes hours to decrease. For a worker in the constant region, there is only an income effect, reducing hours. In the phase-out region, the EITC unambiguously reduces labor supply since there is both a negative substitution effect from the credit being phased-out and a negative income effect from the additional income the credit provides to the taxpayer. Beyond the credit region, taxpayers may decide to reduce their hours of work and receive the credit.

\section{IDENTIFICATION STRATEGY}

We study the labor supply response of unmarried female household heads to the 1987 expansion of the earned income tax credit, which occurred as part of the Tax Reform Act of $1986 .{ }^{16}$ We focus on single women with children because they are the largest group of taxpayers eligible for the EITC, making up approximately 48 percent of the EITC eligible population (Eissa and Liebman 1993). In addition, they are the group most relevant for studying whether the EITC reduces welfare dependency. Finally, they

\footnotetext{
${ }^{15}$ As we discuss later, labor supply theory for a married couple is more complicated. The income effect of the EITC may cause one spouse to leave the labor force.

${ }^{16}$ Throughout the paper, we use "single women with children" and "female household heads" interchangeably.
} 
are the group for which we can most plausibly ignore the joint labor supply decisions of other family members, and thus derive simple predictions from labor supply theory. ${ }^{17}$ We study the 1987 expansion of the credit because it was the largest EITC expansion that was not phased-in over a number of years. ${ }^{18}$ 19 The incentives created by the 1987 expansion of the EITC were reinforced by other tax changes implemented after the Tax Reform Act of 1986, making the total impact on single women with children similar in size to the larger EITC expansions of the 1990s.

The 1987 expansion of the EITC increased the subsidy rate for the phase-in of the credit from 11 percent to 14 percent and increased the maximum income to which the subsidy rate was applied from $\$ 5000$ to $\$ 6080$. This resulted in an increase in the maximum credit from $\$ 550$ to $\$ 851$ (\$788 in 1986 dollars). The phase-out rate was reduced from 12.22 percent to 10 percent. The higher maximum credit and the lower phase-out rate combined to expand the phase-out region. Taxpayers with incomes between $\$ 11,000$ and $\$ 15,432$ became eligible for the credit and faced its phase-out marginal tax rate for the first time in 1987. At every level of earnings, the EITC amount in 1987 was at least as large as it was before the expansion. Therefore, theory predicts that labor force participation of eligible taxpayers will increase in response to the expansion.

\footnotetext{
17 In a two parent family, the credit may reduce the probability of participation for the secondary earner through an income effect. The overall effect on family labor supply will depend critically on the model of labor supply assumed to hold at the household level and on the distribution of earnings within the family. In 47 percent of married couples earning less than $\$ 25,000$, the woman accounts for at least 40 percent of the family's earnings (March 1993 CPS). Therefore, the common assumption that a family's marginal tax rate is determined by the male's earnings may not appropriate for this population. Even for household heads, the simple model may not be sufficient. Jencks and Edin (1993) show that most single mothers receiving AFDC also receive income from boyfriends and extended family members, and often have unreported labor income.

${ }^{18}$ While the new marginal tax rates and maximum credit were immediately implemented in 1987, the EITC budget constraint facing taxpayers did change in 1988 because the constant region was extended. This also extended the point where the credit was entirely phased-out.

${ }^{19}$ While the real value of the maximum earned income tax credit has changed in almost every year since 1975, the early changes were small and mostly due to inflation (the EITC was not indexed for inflation until 1987 ) and the later statutory changes have been phase-in gradually. In addition, we do not yet have enough data to examine the expansions of the 1990s.
} 
The positive impact of the EITC expansion on the average return to work was reinforced by other elements of the Tax Reform Act of 1986 . TRA86 increased the standard deduction for a taxpayer filing as head of household from $\$ 2480$ in 1986 to $\$ 4400$ in 1988 (the standard deduction for single taxpayers rose from $\$ 2480$ to $\$ 3000$ ). TRA86 further reduced the tax liability of taxpayers with children by increasing the deduction per dependent exemption from $\$ 1086$ in 1986 to $\$ 1950$ in 1988 . Finally, the tax schedules were changed. The tax schedule changes were particularly beneficial to head of household filers because the increased standard deduction and exemption amounts meant that in 1988 the typical head of household filer did not jump from the 15 percent tax bracket to the 28 percent tax bracket until her AGI exceeded $\$ 33,565$. In contrast, a single filer would begin paying 28 percent on AGI over $\$ 22,800$.

In contrast to the positive predicted impact of the EITC expansion on the labor force participation of single women with children, the expansion should decrease hours of work for most workers. A more detailed discussion of the impact of the 1987 expansion on hours of work is deferred until section VIII.

Our estimation strategy compares the labor force participation and hours worked of single women with children before and after TRA86. Most single women with children are eligible for the EITC (if they have appropriate incomes) and, if they file tax returns, they usually file as household heads. While the difference between the 1988 and 1986 tax liability of a taxpayer varies by income, we cannot use this variation as the basis of our work because the amount of tax paid by a taxpayer and her labor supply behavior are endogenously determined. Thus the "treatment" in this natural experiment is not a specific change in tax liability. Rather, it is the entire shift in the budget constraint. In practice therefore, we rely on time to identify the responsiveness of female household heads to the EITC and the other aspects of TRA86. Since there may be underlying trends in participation or hours of work and there may be other policy or economic shocks that affect labor market outcomes, we use control groups to allow us to isolate the impact of TRA86 from other factors. A good control group is similar in its characteristics 
to the treatment group -- and therefore likely to respond similarly to the underlying trends or contemporaneous shocks -- but does not receive the treatment.

As we explained earlier, eligibility for the EITC depends on the presence of a child in the tax unit and on income being above zero and below the level at which the credit is completely phased-out. The expansion of the EITC may, however, affect taxpayers with incomes beyond the level at which the credit is completely phased-out since they may reduce their hours (and incomes) and take advantage of the increased credit. Therefore, we use all female household heads (i.e. single women with children) as our primary treatment group. ${ }^{20}$ We use all single women without children as the control group. The difference between the change in labor force participation of single women with children and the change of single women without children is our estimate of the effect of TRA86 on participation. ${ }^{21}$ This is essentially the difference-in-difference approach. It controls for any contemporaneous shocks to the labor force participation of unmarried heads through the change in participation for the control group. ${ }^{22}$ The two identifying assumptions that we make are 1) there are no contemporaneous shocks (other than the tax changes) to the relative labor market outcomes of the treatment and the control groups over the period of the reforms; and 2) there are no underlying trends in participation or hours of work that differ between the two groups.

By including all female heads with children in the treatment group, we are including many taxpayers

${ }^{20}$ We are assuming that the taxpayer's marital status and the presence of children in the tax filing unit are exogenously determined. To test whether our results are sensitive to assuming that fertility decisions are exogenous, we re-estimated our basic model using as our treatment group only women who had a qualifying child over age 5 . Our results did not change.

${ }^{21}$ Contamination of the treatment and control groups (which would bias our results towards zero) should not be a large problem in this application. We have checked our allocation methodology using the CPS-IMF match. We find that 89 percent of women whom we allocate to the treatment group and who file a tax return claim a dependent child on that tax return ( 80 percent of treatment group filers, file as head of household). 95 percent of women whom we allocate to the control group and who file a tax return, do not claim a dependent child on that tax return ( 91 percent file as single). If misallocation of individuals to the treatment group and control group happens at random, then these results imply that we should increase our results by 19 percent.

${ }^{22}$ See Eissa (1995) for an application to married women's labor supply. 
(those with high incomes) who are unlikely to be affected by the EITC. It also increases the importance of the non-EITC aspects of TRA86, since those effects were larger at incomes beyond the phase-out of the EITC. In addition, the broad treatment group makes it difficult to find good control groups. To focus on the impact of the credit on low-income families, we use two alternative treatment groups. The first is female household heads with low levels of education, for which we use two control groups: $:^{23}$ similarly educated single women without children and female household heads with more education. The second control group is more similar to the treatment group on one dimension -- they have children -but less similar on another -- they have higher education levels.

The second additional treatment group is single women with children whom we predict (using exogenous characteristics such as age, race, state, and education) would have earned incomes making them eligible for the EITC. Again we have two control groups for this treatment group: single women without children but with similar predicted incomes, and female household heads with predicted incomes above the EITC maximum earned income.

The advantage of having multiple control groups is that if we find similar results, we can be more confident that we are estimating the actual effect of the tax reforms and not just the effect of other contemporaneous changes or trend differences between the control and treatment groups. Ultimately then, the credibility of our results lies in the consistency of our estimates across different treatment and control groups rather than on any one estimate.

The following table summarizes our treatment and control groups:

\footnotetext{
${ }^{23}$ We use two definitions of low education: less than 12 years of education and exactly 12 years of education.
} 


\begin{tabular}{|c|c|}
\hline Treatment Group & Control Group \\
\hline With children & Without children \\
\hline \multirow{2}{*}{$\begin{array}{l}\text { With children and (less than) } \\
\text { high school education }\end{array}$} & $\begin{array}{l}\text { Without children and (less than) high } \\
\text { school education }\end{array}$ \\
\hline & $\begin{array}{l}\text { With children and more than high } \\
\text { school education }\end{array}$ \\
\hline \multirow{2}{*}{$\begin{array}{l}\text { With children and predicted } \\
\text { income in EITC range }\end{array}$} & $\begin{array}{l}\text { Without children and predicted income } \\
\text { in EITC range }\end{array}$ \\
\hline & $\begin{array}{l}\text { With children and predicted income } \\
\text { beyond EITC range }\end{array}$ \\
\hline
\end{tabular}

\section{DATA}

The data we use are from the 1985 to 1987 and 1989 to 1990 March Current Population Surveys. The March CPS is an annual demographic file of approximately 57,000 households. It includes labor market and income information for the previous year, so the data we have are for tax years 1984 to 1986 and 1988 to 1989 . We do not include 1987 since that is the first year after TRA86, and we want to allow time for taxpayers to adjust their behavior. We do not include years following 1989 because we do not want our results to be affected by the recession which began in 1990 .

The CPS has information on households, families and individuals. However, the relevant unit of analysis for this study is the tax-filing unit. Our tax-filing units are based upon CPS families. Therefore, subfamilies (both related and unrelated) are allocated to separate tax-filing units from the primary family. ${ }^{24}$ We consider any member of the tax-filing unit who is under the age of 19 (or under 24 and a full-time student) to be a dependent child for tax purposes. We do not have sufficient information to

\footnotetext{
${ }^{24}$ To derive income for tax filing units, we add up the income for the individuals in the tax filing unit. We cannot use CPS family income because CPS family income for primary families includes the income of subfamily members.
} 
impose the support test for dependents. In addition, we do not have enough information to impose the EITC six-month residency test. Therefore, we assume that any taxpayer with a child under the age of 19 (or under 24 and a full time student) meets both the dependent child and EITC child requirements.

The sample includes unmarried females (widowed, divorced, and never married) who are between 16 and 44 years old. We exclude any female who is separated from her spouse during the reference period, or who was ill or disabled, in the military, or in school full time during the previous year. We also exclude any woman with negative earned income (due to negative self-employment income), negative unearned income, or with positive earned income but zero hours of work. The resulting sample size, after pooling all five years, is 55,364 observations.

Table II presents summary statistics of the characteristics of the treatment and control groups. Column 1 presents the characteristics of all unmarried females without children (control); column 2 presents characteristics of all unmarried females with children (treatment). There are some noticeable differences between the two groups. Those who have children tend on average to be older $(31.30 \mathrm{vs}$ 26.67 years), less educated (11.99 vs 13.42 years of age), and less likely to be in the labor force (.74 vs .95 probability of participation). Average earnings for women with children are less than earnings for those without children. Conditional on working, however, the two groups have almost identical mean earnings. In columns 3, 4, and 5 we present characteristics for women who have completed less than 12 years of schooling, 12 years, and more than 12 years, respectively. Again there appear to be systematic differences between the attributes of the groups. The more educated the female head is, the more likely she is to be older, to have a smaller family, and to be a member of the labor force.

These summary statistics suggest that any raw differences in labor market outcomes over time between the treatment and control groups must be interpreted with caution, since the differences could reflect non-tax shocks that affect people with certain characteristics differently from people with other characteristics. The methods used to control for demographic differences will be critical to our analysis. 
These results also confirm our earlier point that there is no ideal control group. We will need to compare females with children both to similarly educated females without children and to other females with children but with different education levels. Only if results are consistent across different specifications will we have strong evidence of a tax effect.

\section{Basic Participation Results}

Table III presents labor force participation rates for the treatment groups and control groups in the years before and after the Tax Reform Act of 1986. These figures are unweighted sample means. ${ }^{25}$ In each panel, the first column corresponds to the average participation rate prior to TRA86; the second column to the average after TRA86; and the third column to the change in participation. The differencein-difference estimate of the participation response is in the last column. Panel A presents the results for the first treatment group (all unmarried females with children) and control group (all unmarried females without children). The participation rate of the treatment group increased by a statistically significant 2.6 percentage points (from 73.1 percent to 75.7 percent). The increase for unmarried women without children was 0.1 percentage points (from 95.1 to 95.2 percent). The fact that the participation rate of the control group does not change is important; it suggests that there is not much of an aggregate effect of which to take account. We would be concerned if there were substantial changes in the participation rate for the control group, because, in that case, our difference-in-difference estimator would depend heavily on the quality of the control group. Our first estimate of the participation response then is 2.5 percentage points, with a standard error of 0.7 .

To further examine whether the EITC caused the participation rate of female household heads to rise, we next focus on the subset of females with children who were most likely to be affected by an increase in the EITC -- those with low education. The top part of Panel B presents participation rates

\footnotetext{
${ }^{25}$ Weighted means are almost identical.
} 
for women with children and less than high school education, compared to women with the same level of education and no children, and also compared to more educated women with children. The bottom part of the panel repeats the exercise for individuals with exactly 12 years of education. The participation rate before TRA86 was 47.9 percent for women with children and less than a high school education, compared with 78.1 percent for women without children and less than a high school education, and 91.6 percent for women with children and more than a high school education. After TRA86, there is an increase in the participation rate of 2.8 percentage points (from 47.9 percent to 50.7 percent) for the "less than high school" treatment group. There is a 1.3 percentage point drop in the participation rate of the first control group (females with less than high school education and no children). Taken together, these figures suggest a participation response of 4.2 percentage points. The second control group, females with children and more than high school education, has a small increase in participation of 0.4 percentage points, half its standard error. Thus, using the "less than high school" group generates treatment effects of 2.4 to 4.2 percentage points, both significantly different from zero at the 5 percent confidence level. For the "high school" treatment group, shown in the bottom half of the last panel of Table III, the corresponding range of estimates is 1.9 to 2.2 percentage points.

These results suggest that the labor force participation of unmarried heads of households increased following the Tax Reform Act of 1986. We do not observe a similar increase in the control groups. We observe the largest percentage point response among female heads with less than 12 years of schooling. This is encouraging since they are the most likely to be affected by the EITC. Given the differences in demographic characteristics across the different treatment and control groups, the estimates are surprisingly consistent: 2.5 percentage points for all single women with children and 1.9 to 4.2 percentage points for less educated women with children. ${ }^{26}$

\footnotetext{
${ }^{26}$ We use the relative change in the level of participation as our measure of the tax effect. This approach assumes that the treatment and the control groups have identical percentage-point responses in the level of the participation rate to any underlying trend or non-tax shock. Because the control group and the treatment group have
} 


\section{REgRESSION FRAMEWORK}

Because the treatment and the control groups differ in demographic characteristics, the observed differences in participation outcomes may reflect underlying differences between the treatment and control groups rather than a treatment effect. Controlling for demographic characteristics in a difference in difference approach is important if the composition of the treatment or control groups changes over time and some demographic characteristics are correlated with the dependent variable. In addition, controlling for demographic characteristics reduces the residual variance of the regression and produces more efficient estimates. Finally, by interacting demographic characteristics with a time dummy, we are able to reduce the chance that unknown shocks that differentially affect people with different characteristics are producing a false treatment effect.

\section{$\underline{\text { Specification }}$}

We estimate the probit equation:

very different levels of participation, our results could be sensitive to the specification of the treatment effect. To check the sensitivity of our results, we examined the impact of TRA86 on the relative percent change in nonparticipation. For all unmarried females, non-participation fell by 9 percent in the treatment group and by 2 percent for the control group. In Panel B of Table II, non-participation fell by 5.4 percent for women with children and less than high school education while it rose by 5.9 percent for childless women with less than high school education and fell by 4.8 percent for women with children and more than high school education. In the last half of Panel B, non-participation fell by 10 percent for the treatment and fell by 1.8 and 4.8 percent in the two control groups. Therefore the alternative approach confirms that EITC eligible women decreased their non-participation by more than did women who were less likely to be affected by the EITC.

Another potential concern is that since the participation rate of the control group is so high (95 percent), there is not much scope for the rate to rise after TRA86. While the evidence using the less than high school control group (with a participation rate of 78 percent) provides some reassurance on this point, we examined two other potential control groups: low-educated married women without children and low-educated single men without children. The labor force participation of the married women increased by .2 percent, from 83.9 to 84.1 percent, after TRA86, providing further evidence that the 2.3 percent increase observed for single women with children is larger than that observed for other groups in the economy. The labor force participation of single men rose from 93.5 percent to 94.5 percent. We take this as evidence that our methodology would have been capable of observing a rise in labor force participation by single women without children had one occurred, even though they started from such a high level of participation. 


$$
P\left(l p_{i t}=1\right)=\Phi\left(\alpha+\beta Z_{i t}+\gamma_{0} \text { treatment }_{i}+\gamma_{1} \text { post86 }_{t}+\gamma_{2}(\text { treatment } * \text { post86 })_{i t}\right.
$$

where lfp is a dummy equal to one if a woman reported working at least one hour during the previous

year. $Z_{i r}$ is a vector that includes unearned income, family size, number of preschool children, age and its square, education and its square, and a dummy variable for race (=1 if non-white). $Z_{i r}$ also includes year dummies for 1984,1985 , and 1987 . These variables control for observable differences in the characteristics of the treatment and control group that affect the level of labor force participation. Unobservable differences are controlled for by the variable, treatment, which is equal to 1 for any woman who has a child in her subfamily (and is therefore eligible for the EITC and likely to file as a household head). In our various specifications, membership in the treatment group is defined in several different ways: women with children, women with children and low education, and women with children whose predicted income places them in the EITC region. We expect $\gamma_{0}$ to be negative if women with children have lower participation rates than their counterparts without children, even after controlling for other observable demographic characteristics. post86 is a dummy equal to 1 for any tax year after $1986 . \gamma_{1}$ therefore reflects the average change in labor force participation for both treatment and control groups after the Tax Reform Act of 1986.

A test of the impact of the TRA86 is a test that eligible, unmarried women with children increased their participation after 1987 relative to unmarried women in the control group. It is a test that $\gamma_{2}$, the coefficient on the interaction term between post86 and treatment, is greater than zero. Thus our hypothesis tests are one-tailed tests (the 95th percentile of the t-distribution is 1.64).

\section{Regression Estimates of the EfFect of TRA86 ON LABor Force PaRticipation}

This section presents regression-based estimates of the labor force participation response to the Tax 
Reform Act of 1987 . We begin by using unmarried women with children as the treatment group and unmarried women without children as the control group. We run regressions on a number of samples: all unmarried women, low-educated unmarried women, and unmarried women with earnings predicted to be in the EITC range. In these regressions, treatment is a binary variable that takes on the value of one (treatment group) or zero (control group). ${ }^{27}$ We also present regression results in which we restrict our sample to unmarried women with children and compare women with low earnings capacities (measured by education and predicted income) to women with high earnings capacities.

\section{Children vs No Children: Binary Treatment}

Table IV presents the first set of results in which we use the presence of children as our measure of eligibility for the EITC and the head of household filing status (kids replaces treatment in equation 1). Regressions in column 1 and column 2 use the sample of all unmarried women. The first column excludes demographic characteristics, while the second column includes them. The estimated coefficient on post86, $\gamma_{1}$, is small in magnitude and insignificant in both columns, suggesting that there is no overall trend in average participation for the two groups. The coefficient on kids $\left(\gamma_{0}\right)$ changes dramatically once demographic characteristics are included: from -1.036 to -.224 . This result should not be surprising since females with children have different attributes than women without children. The fact that $\gamma_{0}$ remains significant even after controlling for observable characteristics suggests that having a child reduces labor force participation even controlling for observable demographic variables or that there are unobservable differences across the two groups. In spite of these differences, however, the treatment effect $\left(\gamma_{2}\right)$ changes little when we include demographic characteristics as regressors: it falls from .066 to .058 (with

\footnotetext{
${ }^{27}$ In an erlier version of the paper, we extended these results to allow treatment to be a continuous variable incorporating the predicted probability of being in the EITC range as well as the value of the EITC available at each level of income. The impact of the EITC on the probability of labor force participation in these additional specifications is almost identical to the binary treatment specification. The results are available from the authors.
} 
a standard error of .034). This is an important observation since a large change in the interaction coefficient would have signaled that our results are sensitive to the particular regression specification. In addition, it would suggest that our identifying assumption that the treatment*post86 interaction term is exogenous, and therefore uncorrelated with the other regressors, was violated.

The coefficients on the other demographic characteristics all have the expected signs. Females with unearned income have lower probabilities of participation, ${ }^{28}$ as do females with preschool children and with larger families. Older women have lower probabilities of participation, as a cohort effect would predict. ${ }^{29}$ Finally, educated women are more likely to be in the labor force than less educated women, although this relationship is nonlinear.

The probit is a nonlinear model; therefore, the coefficients cannot be used directly as marginal effects. Since the treatment effect variable (kids*post86 interaction) is discrete, we calculate the effect of the TRA86 by predicting two probabilities of participation, one with the interaction variable set equal to one and the other with the interaction term set equal to zero. The treatment effect is the average (over the sample of post 1987 women with children) of the difference in the two probabilities of participation. The last row in Table IV presents estimates of the treatment effect. We find that female heads had a 1.4 percentage point higher probability of entering the labor force as a result of the combined impact of the expansion of the earned income tax credit and the other TRA86 reductions in tax liability for single women with children. ${ }^{30}$ The standard error on this estimate is 0.8 percentage points. This is

\footnotetext{
${ }^{28}$ The income effect implies that females with high unearned income are less likely to participate. If having unearned income is positively correlated with high wage rates, then the substitution effect might cause women with higher unearned income to participate more. Since most of unearned income for this population is from AFDC rather than from capital income, we expect the income effect to dominate.

29 The derivative of all three age terms (averaged over the entire sample) is -.001 percentage points.

30 The treatment effect estimated using the mean characteristics of the post 1987 sample is quite similar. We find a participation response of 1.6 percentage points.

${ }^{31}$ Appendix B explains how we calculated the standard errors.
} 
significantly different from zero at the 95 percent confidence level under our one-tailed test.

This estimate is likely to be smaller than the response of the targeted population since the treatment group includes some women who have high earning potential, and are therefore unlikely to be affected by the EITC expansion. We should expect to find stronger responses to the EITC once we restrict the sample to women with lower earning potential. In columns 3 and 4 , we present results for samples selected by education levels. Column 3 presents the results for the less than high school sample. As expected, the magnitude of $\gamma_{2}$ is larger for less educated women than for the entire sample. The implied treatment effect is 3.7 percentage points (with a standard error of 2.3 percentage points), more than double the basic result. For the high school educated (column 4), the predicted response to the expansion of the credit is 2.0 percentage points. ${ }^{32}$

The results for different education groups support the view that the treatment response may be linked to the credit expansion and not solely to other aspects of the TRA86, since single women who are more likely to be eligible for the EITC had greater increases in labor force participation. Nonetheless, the low education groups do not correspond exactly to the EITC eligible population. Some workers with low education will have incomes that are higher than the maximum for receiving the EITC and many women with more than a high school education will have incomes qualifying them for the EITC. In order to have a treatment group that more closely matches the EITC eligible population, we base eligibility on an exogenous estimate of earned income. To generate this measure, we estimate an earnings equation using the sample of earners prior to 1987 :

$$
y_{i t}^{\text {earned }} \mid\left(y_{i t}^{\text {earned }}>0\right)=X_{i t} \beta+\epsilon_{i t} \quad t<1987
$$

In this regression, $\boldsymbol{X}_{i t}$ includes family size, the number of preschool children, the state unemployment rate

\footnotetext{
${ }^{32}$ The results in column 4 do not include the education variables since everyone in the sample has the same level of education.
} 
and dummies for age (28), education (10), race (equal to 1 if non-white), year (2), and central city. Using the estimated coefficients and individual characteristics, we predict earned income for each woman in the sample. ${ }^{33}$

Using only the sample of women whose predicted earned income is in the EITC range (approximately 78 percent of the entire sample), ${ }^{34}$ we re-estimate equation (1). Column 5 of Table IV presents the results. Again, we find a pattern similar to that in the basic set of regression results. Following the TRA86, unmarried females with children increased their participation (relative to females without children) by 1.6 percentage points. This estimate has a standard error of 1.0 .

To summarize, we find that controlling for demographic characteristics does not affect the basic difference-in-difference estimates of the labor force participation effect of the TRA86. The treatment effect ranges from 1.4 (for all female heads) to 3.7 percentage points (for the less than high school educated). The samples containing a higher proportion of women who are likely to be affected by the EITC generate larger treatment effects.

\section{Female Household Heads with Different Levels of Education and Predicted Earnings}

Table $\mathrm{V}$ presents results of regressions using a sample that includes only unmarried females with children. In column 1, the treatment group is female heads with less than 12 years of schooling and the

${ }^{33}$ In this methodology, we exclude from the treatment group taxpayers whom we predict to have earnings beyond the phase-out range. In fact, some nonparticipants with predicted earnings (using coefficients estimated on an pre-1987 sample) beyond the phase-out range may choose to participate at a lower level of earnings in order to take advantage of the increased credit (this is analogous to workers beyond the phase-out reducing their hours to take advantage of an increase in the EITC). Therefore, our sample does not exactly match the sample of all people whose participation could be affected by the expansion of the EITC.

${ }^{34}$ We use 1988 EITC rules to predict eligibility. In 1988, the maximum earned income making one eligible for the credit was ${ }^{5} 18,576$. We predict that 87 percent of our sample of unmarried females with children was eligible for the EITC. Although this estimate seems large, we note three points. First, our sample is made up of relatively young females (16 to 44 years old). Second, we exclude from our calculation of earned income any earnings of children or other relatives in the households. So household eamings may be greater. Finally, median family income for female householders (with related children) was $\$ 12,979$ in 1989 (Statistical Abstract of the United States, 1991). 
control group is female heads with more than 12 years of schooling. In column 2 the treatment group is female heads with predicted earnings within the EITC eligibility range and the control group is female heads with incomes beyond the EITC range. In both regressions we find that the treatment group increased its labor force participation after the expansion of the credit by 1.6 percentage points, similar to previous results. However, the standard errors are very large in these regressions and we cannot rule out the possibility that the treatment effect is zero. Since 87 percent of household heads are predicted to be eligible for the credit, it is clear that our control groups contain many EITC eligible taxpayers. This may explain the low precision of these estimates.

\section{Alternative EXPlanations for the PARTiCiPATION ReSPONSE}

In sections $\mathrm{V}$ and VII, we presented evidence that single females with children increased their labor force participation relative to single females without children after 1987 , and that this increase in labor force participation was especially large among women with low levels of education and low predicted earnings. While the Tax Reform Act of 1986 is one explanation for this increase in labor force participation, there are a number of other potential explanations. In this section we discuss four alternative explanations: prior trends in labor force participation. macroeconomic shocks, changes in AFDC benefit levels, and labor market shocks which differentially affect people with different demographic characteristics.

\section{Prior Trends in Labor Force Participation}

Labor force participation rates for all women increased from 37.1 percent in 1959 to 57.4 percent in 1989. If long-run trends in labor force participation differ between females with and without children or across women with different education levels, then we risk interpreting pre-existing differences in labor supply patterns as treatment effects. In this section, we present evidence on the longer trends in labor 
supply behavior of the treatment and control groups and show that these trends cannot explain our results.

Figure 2 shows the labor force participation rate for unmarried females, aged 16 to 44 , between 1981 and 1992. We present separate trends for women with and without children. The labor force participation rate for women without children does not appear to be trending either upward or downward during this period. The participation rate for women with children seems to be much more sensitive to the business cycle. There also appears to be an increase in labor force participation after 1986 for women with children, while the rate for women without children trends upward only slightly.

In order to rigorously check these visual impressions, we estimated a probit regression of labor force participation on 12 year dummies, a dummy for children, and interactions of the children and year dummies. The coefficients on these interaction variables represent annual deviations from the average difference in participation between females with children and those with no children. These coefficients and the maximum EITC are plotted in Figure 3. The figure shows quite clearly that the difference in participation rates between females without children and females with children declines (the coefficients become less negative) following the 1987 increase in the maximum credit. The participation rate difference seems to track the maximum EITC quite closely with a one year lag. It seems safe to conclude that the response estimated for the 1987 expansion does not reflect pre-existing trend differentials in the labor force participation of females with children and females without children. Indeed, the long-run evidence seems to confirm the conclusion that the relative labor force participation of women with children increased after 1986.

\section{The Business Cycle}

As we noted, figure 2 shows that there is a noticeable difference between single women with and without children in the sensitivity of their labor force participation to macroeconomic shocks. The recession of 1982 seems to have affected the former group in a particularly severe manner. This suggests 
that the business cycle is potentially an important part of our story since it differentially affects the treatment group and the control group. In Figure 4 we present the labor force participation rate for females heads of households, the maximum EITC (in constant dollars), and the national unemployment rate for females for each year from 1979 to 1992 . This figure highlights two important points. First, there is a noticeable economic recovery occurring between 1986 and 1988 . During this period, the national unemployment rate for females fell by 1.8 percentage points, from 7.1 to 5.3 percent. ${ }^{35}$ Second, with the exception of the 1990 recession, the maximum EITC generally moves in the opposite direction of the unemployment rate. Because both a reduction in the unemployment rate and an increase in the EITC should increase labor force participation, it is not possible to isolate the effects of the credit from the effects of the business cycle using the national unemployment rate.

Research has shown that the employment and earnings status of less educated, younger workers is closely related to state and local labor market conditions (Bartik 1991, Freeman 1991). To purge the effects of general business cycle movements, we therefore use variation in the unemployment rate across states and over time. ${ }^{36}$ We enter the contemporaneous state unemployment rate in our regressions. Because the labor force participation behavior of the treatment group is generally more sensitive to the business cycle, we also interact this unemployment rate with the treatment dummy.

The first column of Table VI presents results from this procedure. The treatment group is all female heads with children and the control group is all single females without children. Therefore, these results are comparable to column 2 of Table IV. Adding the state unemployment rate to equation (1) generates

\footnotetext{
${ }^{35}$ For female heads of households, the unemployment rate fell from 9.8 to 8.1 percent.

${ }^{36}$ We use the state unemployment rate for the entire labor force rather than for females only. The latter will be endogenous to the credit itself; if a female head is in the labor force, an increase in the credit may reduce the unemployment rate; if she is out of the labor force, an increase in the credit may either increase or decrease the unemployment rate.
} 
a stronger response: the predicted participation effect becomes 3.0 percentage points, instead of $1.4 .^{37}$

Thus controlling for macroeconomic conditions does not overturn the basic result that there was a relative increase in labor force participation by single women with children in the time period following the Tax Reform Act of $1986 . .^{38}$

\section{$\underline{\text { AFDC }}$}

The EITC is not the only government program which affects low income families with children without affecting other families. Changes in AFDC benefit levels offer another explanation for our findings. ${ }^{39}$ In column 2 of Table VI, we add the state maximum monthly AFDC benefit to the regression in column 1 . The benefits are adjusted by family size so women with no children get a zero benefit. We find that the predicted participation response falls slightly from 3.0 to 2.8 percentage points.

\section{Other Shocks to Observable Characteristics}

It is possible that the measured tax response is the result of unknown shocks that are correlated with

${ }^{37}$ We checked the robustness of all of the unemployment rate regressions in two ways. First, we estimated regression (1) with state dummies, interacted with both kids and time. The results were similar: the interaction coefficient increased in value. Second, we checked to see if the results are driven by any one state and found that this was not the case.

38 The counter-intuitive impact of the unemployment rate variable can be understood as follows. While figure 2 suggests that the labor force participation rate of women with children was more sensitive to the business cycle over the 1980s, in our period (1984-1986 and 1987-1988) the reverse was true -- women without children were more responsive (the interaction of kids with the unemployment rate was positive). The unemployment rate fell during this period. Therefore women without children increased their labor force participation over this period relative to what it would have been if the unemployment rate had not been falling. By controlling for this relative increase in participation, we reduce the participation increase of the control group, thereby finding a larger difference between the treatment and control group.

${ }^{39}$ State Medicaid expansions and welfare-to-work programs could also affect women with children differently than women without children. The increase in the income cap for Medicaid eligibility would be predicted to increase the labor supply of female heads. However, the expansions were adopted in most states only in 1989, and even then it was only for women with children 8 years and under (Yelowitz 1994). State workfare programs, which would also be predicted to increase labor force participation of female heads, had only been proposed by 6 states as of the summer of 1988 (Fishman and Weinberg 1992), so they are unlikely to explain our findings. 
demographic characteristics that differ between the treatment group and the control groups. For example, non-white women may have been induced to enter the labor force at this period for reasons other than the TRA86. We have no good story for why that may be, perhaps a shock to tastes for work, or perhaps changes in incentives that we have not captured. In any case, since female heads of households are more than twice as likely to be non-white than are unmarried females with no children (14 percent vs 33 percent), such shocks could drive our results. To address these concerns, we re-estimate the basic equation including interaction terms between the time dummy and observable demographic characteristics. ${ }^{40}$ The characteristics that most separate women with children from their counterparts with no children are age and race (we have already separated the groups by education).

Column 3 of table VI shows that accounting for shocks that affect people differently depending on their age or their race does not influence the results in an appreciable way. Including interactions between the post86 variable and age and race ( 1 if non-white) causes the predicted participation response to increase from 1.4 percentage points to 1.7. A $\chi^{2}$ tests fail to reject the hypothesis that the expanded models are equivalent to the basic model (column 2 of Table IV). We conclude that our findings are not explained by changes in participation behavior of women of different age or of different race.

Demographic characteristics such as age and race may have a different effect on participation for female household heads than for women with no children. In our basic regressions, we restrict the coefficients on demographic variables to be constant across our treatment and control groups. Since this could bias our results, we have also run regressions interacting age and race with the kids dummy. The results (presented in column 4) show that the estimated treatment effects falls only slightly to 1.2 percentage points.

\footnotetext{
${ }^{40}$ Of course, we cannot rule out unknown shocks to unobservable characteristics.
} 


\section{ESTIMATES OF THE EFFECT OF THE EITC ON HOURS OF WORK}

More than half of all EITC recipients are in the phase-out region of the credit. For these taxpayers the EITC is predicted to reduce hours of work since the EITC increases both their income and their marginal tax rates. ${ }^{41}$ The expansion of the EITC legislated in the Tax Reform Act of 1986 added taxpayers with incomes between $\$ 14,081$ and $\$ 22,021$ (in 1992 dollars) to the phase-out range, raising their marginal tax rates by ten percentage points. In this section of the paper, we examine whether this expansion of the phase-out range reduced the hours of work of women with children relative to women without children. Thus we use the same difference-in-difference methodology that we used to examine labor force participation.

\section{The Predicted Impact of the EITC Expansion on Hours of Work}

Figure 5 displays the 1986 and 1988 Earned Income Tax Credits (in 1992 dollars) as functions of income. The predicted impact of the EITC expansion on hours of works depends on the taxpayer's income. For most workers in region A (incomes between $\$ 0$ and $\$ 14,081$ ), the EITC expansion is predicted to have an ambiguous impact on hours of work since the expansion had offsetting income and substitution effects. ${ }^{42}$ Workers in region B (incomes between $\$ 14,081$ and $\$ 25,000$ ) are predicted to reduce their hours of work because they are either in the expanded phase-out region and face a 10 percent higher marginal tax rate in addition to having their incomes increased or because they have incomes just beyond the expanded phase-in region and might reduce their hours of work to take advantage of the credit. Workers in region $C$ (incomes above $\$ 25,000$ ) are unlikely to be affected by the increase in the

\footnotetext{
${ }^{41}$ For phase-out region EITC recipients who would have been out of the labor force in the absence of the EITC, the EITC unambiguously increases their hours of work.

42 The exception is workers between $\$ 7400$ and $\$ 8321$ who only have a negative income effect from the expansion.
} 
${\text { credit. }{ }^{43} 44}^{4}$

In the empirical work which follows, we examine the relative change in hours for women with and without children who are predicted (based upon exogenous characteristics) to have incomes in the various regions. Because we examine the hours distribution conditional on working, we are implicitly assuming that any EITC-caused increase in participation in the post 1987 period did not alter the hours distribution. We choose not to impose a selection model on the data for two reasons. ${ }^{45}$ First, to identify a selection model we would need a policy shift that affects participation separately from hours of work. TRA86 does not provide us with such a shift. Therefore, any attempt to estimate a selection model would be heavily dependent on the specification chosen. Second, recent research suggests that inferences in labor supply models are extremely sensitive to the model chosen (Mroz 1987, Zabel 1993). Our failure to account for new participants should bias upwards our estimates of the reduction in hours due to the EITC (i.e. make them less negative). New participants are likely to enter the labor force with earnings and hours below what we predict from their exogenous characteristics. This will occur if unobserved factors (such as a greater taste for leisure) which explain their nonparticipation compared to others with the same exogenous characteristics also cause them to choose fewer hours of work.

\footnotetext{
${ }^{43}$ We have replicated all the results in this section using a six region specification instead of the three region specification. The conclusions in this section do not change with the more detailed specification.

44 The TRA86 tax rate changes reinforced the effect of the EITC on the hours of work of household heads relative to single filers. TRA 86 reduced marginal tax rates by between 3 and 8 percentage points for most single taxpayers with incomes in the EITC phase-out range, while reducing marginal tax rates for household heads by only 2 to 3 percentage points. Thus the substitution effect from TRA86 should cause a larger increase in hours from single taxpayers than from household heads. In addition, as we explained in the participation section, the new TRA86 brackets, through their interaction with the increased dependent exemptions and standard deductions, reduced tax liability by more for head of household filers than for single filers. Thus the tax bracket income effect works in the same direction as the EITC increase, and hours of work by household heads should fall relative to hours of work of single taxpayers.

${ }^{45}$ Despite our lack of identification, for completeness we have estimated a Heckman-type selection model. Our conclusions are not altered by these additional results. The results are available from the authors.
} 


\section{Regression Estimates of the Impact of the EITC on Hours of Work}

Table VII shows that in all three predicted earnings regions, mean hours of work increased for both women with and without children after 1987. The increase was larger for women with children, but not by a statistically significant amount. Thus there does not appear to be any evidence that EITC-eligible women in the expanded phase-out region reduced their hours of work relative to ineligible women.

Regression estimates of the impact of the EITC on hours of work look quite similar to the differencein-difference results using only mean hours. We estimate an OLS regression:

$$
\text { Hours }_{i t}=\alpha+\beta Z_{i t}+\gamma_{0} k i d s_{i}+\gamma_{1}{\text { post } 8 \sigma_{t}+\gamma_{2}(k i d s * \text { post86 })_{i t}}
$$

Once again, $\mathrm{Z}$ includes age, age squared, education, education squared, family size, and dummy variables for race and the presence of pre-school children. Kids equals one for unmarried women with children. Thus the key coefficient is $\gamma_{2}$ the coefficient on the kids*post86 interaction.

Table VIII displays results from five different samples based upon predicted income. In columns 1 and 2 , the entire sample is divided based upon whether the taxpayer is predicted to have income in the (1988) EITC range. In both regressions the interaction coefficient is small, positive, and not statistically different from zero. Columns 3, 4, and 5 separate the sample into regions A, B, and C (see figure 5) based upon predicted income. Once again, the interaction terms are positive and are not statistically different from zero. There is certainly no evidence of a relative decrease in hours worked by women in the expanded phase-out region who are eligible for the EITC compared with women who are not eligible. $^{46}$

46 We have tried a variety of other specifications, none show any evidence of a reduction in hours by women with children in the phase-out. 


\section{Discussion of Results}

This section interprets the participation rate and hours of work estimates. It begins by discussing whether we can separate the impact of the 1987 expansion of the EITC from other aspects of TRA86. Next it asks whether we should consider the participation rate estimates to be a large effect. Finally, it presents a number of explanations for why we find a positive participation response and no hours response. Two types of explanations are discussed: 1) explanations for why the participation response may in fact be more elastic than the hours response; and 2) explanations for why our hours methodology may be less likely than our participation methodology to measure a response.

\section{Separating the Impact of the EITC from Other Parts of the TRA86}

While our methodology does not allow us to separately identify the impact of the expansion of the EITC from the other aspects of the Tax Reform Act of 1986 which favored single parents with children, we can eliminate part of the non-EITC impact by separating the reduced tax liability from having one child in the subfamily from the reduced tax liability from having additional children. In the period that we study, the EITC expansion mattered only for the first child in the tax unit. Similarly, the advantages of the head of household filing status come from the initial child. In contrast, additional dependent exemptions are available for each additional child. Thus if families with multiple children were more likely to increase their labor force participation than families with one child, then this part of the response was due to the expansion of the dependent exemption and not to the EITC.

To disentangle the EITC and head of household effect from the dependent exemption effect, we estimate a regression in which we interact a kid2 dummy (which equals one if there is more than one child in the tax filing unit) with the post86 dummy. The reduction in tax liability that comes from eligibility for the EITC or the head of household filing status is much larger than the gain to an additional dependent exemption (above the first). Therefore, we expect to find little additional response by 
taxpayers with two or more children. Column (5) of table VI confirms our expectations. The coefficient on the kid ${ }^{*}$ post 86 interaction is only .001 . We conclude, therefore, that the 1.4 percentage point response is a result of the EITC expansion, the increased head of household standard deduction, and the increase in the dependent exemption for the first child.

To interpret the 1.4 percentage point response for the average head of household in our sample, we refer to Figure 6. Figure 6 displays the change in the EITC between 1986 and 1988 (in constant 1992 dollars), as well as the change in tax liability due to the other TRA86 changes for a head of household filer relative to the change in tax liability for a single filer. The figure shows that the TRA86 changes most reinforced the gains from the EITC expansion at $\$ 11,600$, roughly the average earnings for women with children in our sample. At that earnings level, non-EITC aspects of TRA86 reduced a household head's tax liability relative to a single filer by $\$ 453$ while the EITC expansion reduced in by $\$ 733$. Therefore, we should think of the 1.4 percentage point response as resulting from a reduction in tax liability that is equivalent to a $\$ 1186$ increase in the maximum earned income tax credit.

\section{How Large are the Estimated Participation Effects?}

Over the period of the expansion, real spending on the earned income tax credit increased from 2.5 billion dollars to 7.2 billion dollars. If 60 percent of this money went to female heads of households ${ }^{47}$, then the additional EITC spending on female heads of households is approximately 2.8 billion dollars. If all of the observed 1.4 percentage point increase in participation were due to the EITC then that would imply that the EITC resulted in 124,600 new labor force participants from the population of heads of households. Per new entrant, the federal government is spending at least $\$ 23,000$ (1992 dollars) on the

\footnotetext{
${ }^{47}$ Approximately 60 percent of all EITC recipients in 1988 filed head of household returns (Eissa and Liebman 1993).
} 
EITC. ${ }^{48}$ Therefore, the EITC appears to be a very expensive way to increase labor force participation. However, the main purpose of the EITC is to transfer income to the poor. It is an added bonus that the program appears to encourage labor force participation, since other programs that transfer income to the poor discourage labor supply.

\section{Why Do We Find a Participation Effect but No Hours Effect?}

Economic theory suggests that the 1987 expansion of the EITC should increase labor force participation and reduce the hours of work of EITC recipients who are already in the labor force. Our finding that the expansion did indeed increase labor force participation, but did not reduce hours worked is somewhat puzzling. We offer four explanations:

1) Labor force participation is more elastic than hours of work.

It is common for studies of labor supply to find that labor force participation responds more than hours of work to a change in the net wage. Recent studies such as Mroz (1987), Zabel (1994) and Triest (1992) all find greater participation responses.

2) EITC recipients receive the credit as a lump sum and therefore do not perceive the marginal effect of the phase-out.

There is strong evidence that many EITC recipients do not know that they receive the credit, and that even those who are aware of it do not understand how it works. Interviews we conducted during August 1993 in Cambridge, Massachusetts among potential recipients suggested virtually no awareness of the credit (see Eissa and Liebman (1993) for details). This observation was confirmed by the experience of one author (Liebman) as an IRS VITA volunteer in March and April 1994, which revealed that even past recipients were often unaware of the credit. More extensive interviews conducted in Chicago and

${ }^{48}$ A fuller analysis would subtract AFDC payments saved and additional income tax received (though most EITC recipients have a negative tax liability). 
described in Olson and Davis (1994) similarly found low awareness and understanding of the credit.

Taxpayers do not have to know about or understand the EITC for it to affect their labor force participation. Suppose a single mother on the margin between work and welfare decides to get a job. At the end of the year, she goes to a paid tax preparer. She receives a large tax refund due to the EITC, but does not learn where it came from. Nonetheless she decides that she was better off this year than last year and stays in the labor force. Her neighbor who was similarly on the margin between welfare and work and chose to stay on welfare observes that her neighbor who worked seems to be better off that she was. So she starts working. Thus the EITC could be encouraging labor force participation even if recipients do not know it exists.

Almost all recipients of the EITC receive the credit in a single payment as part of their annual tax refund check. Low usage of the early payment option could indicate that recipients are unaware of the EITC. It could also indicate that even if they are aware of the credit, they perceive it as a lump sum benefit. In this case the EITC would be predicted to have an income effect on hours of work, but it is unlikely to have a substitution effect.

Since recipients are not observing the credit in their weekly paychecks, they may not perceive the marginal impact of the credit. This could explain why we find no hours response to the expansion to the credit. On the other hand, if EITC recipients chose how many hours to work on an annual basis then it may not matter whether they understand the credit. A taxpayer who works an extra week this year may realize that she is only better-off by half of her pre-tax earnings. She need not understand which elements of the tax code produced the 50 percent marginal tax rate.

If lack of knowledge of the credit is to explain both the positive participation response to the expansion of the credit and the lack of an hours response, then taxpayers must be making participation decisions on an annual basis and be deciding how to work based on the net incomes in their paychecks. We are not aware of any evidence that either supports or refutes this model of decision making. 


\section{3) Our earnings predictions are not precise enough to allow us to measure a small hours effect.}

In order to avoid the problem of the tax rate and the hours decision being endogenously determined, we assign taxpayers to EITC regions using earnings equations. These equations have very low R2s. Therefore, we are assigning many taxpayers to incorrect regions. These predictions may not be accurate enough for us to find an hours effect, especially if the hours effect is small. In our participation regressions we do not need to assign taxpayers to a particular EITC region and therefore we are much less reliant on earnings predictions. ${ }^{49}$

4) An unknown positive shock to the labor demand for single women with children occurred.

Since we observe both participation and hours of work increasing for single women with children relative to single women without children, it is possible that some unknown positive shock can explain our findings. In this paper, we have considered a number of likely candidates for such shocks, and none of them eliminate the TRA86 effect. However, it is impossible to rule out all unknown shocks.

\section{Conclusion}

The 1987 expansion of the EITC and other aspects of the Tax Reform Act of 1986 reduced the relative tax liabilities of EITC-eligible household heads by up to $\$ 1186$ (1992 dollars). We estimate that this expansion increased labor force participation among female household heads by 1.4 percentage points, from 73.1 to 74.5 percent. While there are a number of possible explanations for this evidence, we find the combined impact of the 1987 expansion of the EITC and the other provisions of TRA86 to be the most convincing explanation. We have shown that the increase in participation was largest among low-educated and low-income women with children, and that controlling for aggregate labor market conditions and changes in AFDC benefits does not alter our findings.

\footnotetext{
${ }^{49}$ Another possibility is that it is much easier to measure accurately a binary decision like participation decision than it is to measure hours worked. Workers may report round numbers for hours worked, so that it may take a large change in hours before the change appears in a survey.
} 
Between 1990 and 1996, the maximum earned income tax credit increased from $\$ 1023$ to $\$ 3200$ (1992 dollars) for a family with two children. Since our methodology did not allow us estimate the underlying preference parameters of our sample, we cannot make precise predictions of the participation response to the more recent expansions. Our evidence suggests, however, that the recent expansions of the EITC will increase participation by female household heads. There may be decreasing returns to EITC expansions, however, if the non-participating population remaining after each increase is further from the participation-non participation margin.

When we apply our same methodology to hours of work, we find no evidence that the expansion of the EITC decreased hours of work for people already in the labor force. One possible explanation for the differential responsiveness of low income women on the participation and hours margins is that taxpayers are unaware of the credit and that they perceive the credit as a lump sum when they receive their tax refunds. While our finding that the 1987 expansion of the EITC did not decrease hours of work is encouraging, we think it will be important to reexamine this issue as the EITC expands. Awareness of the EITC is likely to increase as the maximum credit triples, and this could result in a greater sensitivity to the marginal tax rate imposed by the phase-out of the credit. In addition, since the lump sum payment of the EITC may explain the lack of hours responsiveness, it would be unwise to apply these results to other increases in marginal tax rates that operate through regular payroll deductions.

One final point is in order. A full evaluation of a transfer program like the EITC requires more than just an estimate of the distortionary impact of the program on the labor supply of transfer recipients. It also requires information on the value of the additional income received by program beneficiaries as well as the change in the amount of leisure that they consume. This must be balanced against the net income lost by taxpayers and the associated deadweight losses. Since both the welfare payments and the taxes involve deadweight losses, the desirability of the program depends on the weights assigned to changes in income at different income levels. A full comparison among alternative tax and transfer 
systems would also evaluate the technology of compliance and administration (Slemrod, 1990). This is particularly true in the case of the EITC where the tax system is performing functions that have traditionally been the responsibility of the welfare system (Alstott, 1995).

Ultimately, the earned income tax credit is an income transfer program. Compared to other elements of the welfare system, the EITC appears to produce little distortion of work incentives. Therefore, if policy-makers want to redistribute income to the working poor and are comfortable with the tradeoffs involved in using the tax system rather than the welfare system to administer transfers, the EITC seems to be a way to do so with minimal efficiency costs. 
APPENDIX A

EARNED INCOME TAX CREDIT PARAMETERS: 1975-1996

\begin{tabular}{|c|c|c|c|c|c|}
\hline YEAR & $\begin{array}{l}\text { PHASE-IN } \\
\text { RATE }\end{array}$ & $\begin{array}{l}\text { PHASE-IN } \\
\text { RANGE }\end{array}$ & $\begin{array}{l}\text { MAXIMUM } \\
\text { CREDIT } \\
\end{array}$ & $\begin{array}{l}\text { PHASE-OUT } \\
\text { RATE }\end{array}$ & $\begin{array}{l}\text { PHASE-OUT } \\
\text { RANGE }\end{array}$ \\
\hline $1975-1978$ & $10.0 \%$ & $\$ 0-\$ 4,000$ & $\$ 400$ & $10.0 \%$ & $\$ 4,000-\$ 8,000$ \\
\hline $1979-1984$ & $10.0 \%$ & $\$ 0-\$ 5,000$ & $\$ 500$ & $12.5 \%$ & $\$ 6,000-\$ 10,000$ \\
\hline $1985-1986$ & $11.0 \%$ & $\$ 0-\$ 5,000$ & $\$ 550$ & $12.22 \%$ & $\$ 6,500-\$ 11,000$ \\
\hline 1987 & $14.0 \%$ & $\$ 0-\$ 6,080$ & $\$ 851$ & $10.0 \%$ & $\$ 6,920-\$ 15,432$ \\
\hline 1988 & $14.0 \%$ & $\$ 0-\$ 6,240$ & $\$ 874$ & $10.0 \%$ & $\$ 9,840-\$ 18,576$ \\
\hline 1989 & $14.0 \%$ & $\$ 0-\$ 6,500$ & $\$ 910$ & $10.0 \%$ & $\$ 10,240-\$ 19,340$ \\
\hline 1990 & $14.0 \%$ & $\$ 0-\$ 6,810$ & $\$ 953$ & $10.0 \%$ & $\$ 10,730-\$ 20,264$ \\
\hline $1991^{\mathrm{a}}$ & $\begin{array}{l}16.7 \%^{1} \\
17.3 \%^{2}\end{array}$ & $\$ 0-\$ 7,140$ & $\begin{array}{l}\$ 1,192 \\
\$ 1,235\end{array}$ & $\begin{array}{l}11.93 \% \\
12.36 \%\end{array}$ & $\$ 11,250-\$ 21,250$ \\
\hline $1992^{a}$ & $\begin{array}{l}17.6 \%^{1} \\
18.4 \%^{2}\end{array}$ & $\$ 0-\$ 7,520$ & $\begin{array}{l}\$ 1,324 \\
\$ 1,384\end{array}$ & $\begin{array}{l}12.57 \% \\
13.14 \%\end{array}$ & $\$ 11,840-\$ 22,370$ \\
\hline $1993^{a}$ & $\begin{array}{l}18.5 \%^{1} \\
19.5 \%^{2}\end{array}$ & $\$ 0-\$ 7,750$ & $\begin{array}{l}\$ 1,434 \\
\$ 1,511\end{array}$ & $\begin{array}{l}13.21 \% \\
13.93 \%\end{array}$ & $\$ 12,200-\$ 23,050$ \\
\hline 1994 & $\begin{array}{l}26.3 \%^{1} \\
30.0 \%^{2} \\
7.65 \%^{3}\end{array}$ & $\begin{array}{l}\$ 0-\$ 7,750 \\
\$ 0-\$ 8,425 \\
\$ 0-\$ 4,000\end{array}$ & $\begin{array}{l}\$ 2,038 \\
\$ 2,528 \\
\$ 306\end{array}$ & $\begin{array}{l}15.98 \% \\
17.68 \% \\
7.65 \%\end{array}$ & $\begin{array}{l}\$ 11,000-\$ 23,755 \\
\$ 11,000-\$ 25,299 \\
\$ 5,000-\$ 9,000\end{array}$ \\
\hline $1995^{b}$ & $\begin{array}{l}34.0 \%^{1} \\
36.0 \%^{2} \\
7.65 \%^{3}\end{array}$ & $\begin{array}{l}\$ 0-\$ 6,240 \\
\$ 0-\$ 8,760 \\
\$ 0-\$ 4,160\end{array}$ & $\begin{array}{l}\$ 2,122 \\
\$ 3,154 \\
\$ 318\end{array}$ & $\begin{array}{l}15.98 \% \\
20.22 \% \\
7.65 \%\end{array}$ & $\begin{array}{l}\$ 11,440-\$ 24,719 \\
\$ 11,440-\$ 27,038 \\
\$ 5,200-\$ 9,357\end{array}$ \\
\hline $1996^{b}$ & $\begin{array}{l}34.0 \%^{1} \\
40.0 \%^{2} \\
7.65 \%^{3}\end{array}$ & $\begin{array}{l}\$ 0-\$ 6,490 \\
\$ 0-\$ 9,110 \\
\$ 0-\$ 4,330\end{array}$ & $\begin{array}{l}\$ 2,206 \\
\$ 3,644 \\
\$ 331\end{array}$ & $\begin{array}{l}15.98 \% \\
21.06 \% \\
7.65 \%\end{array}$ & $\begin{array}{l}\$ 11,900-\$ 25,705 \\
\$ 11,900-\$ 29,203 \\
\$ 5,410-\$ 9,737\end{array}$ \\
\hline \multicolumn{6}{|c|}{$\begin{array}{l}\text { 'Families with one qualifying child. } \\
2 \text { Families with two or more qualifying children. } \\
3 \text { Taxpayers with no qualifying children. } \\
\text { a Basic credit only. Does not include supplemental young child credit or health insurance credit. } \\
\text { b Assumes annual inflation rate of four percent. } \\
\text { Source: The Green Book and authors' calculations from OBRA93. }\end{array}$} \\
\hline
\end{tabular}




\section{APPENDIX B}

The estimated treatment effect is a nonlinear function of the parameter estimates. To obtain standard errors for the predictions, we use the delta method which provides a linear approximation of the asymptotic variance. Our predictions are averages over the post-1986 sample of women with children.

Let

$$
G(\theta)=\frac{1}{N} \sum_{i=1}^{N}\left[\Phi\left(X_{i} \theta \mid D=1\right)-\Phi\left(X_{i} \theta \mid D=0\right)\right]
$$

where $\theta=$ estimated parameters

$\Phi=$ normal cumulative distribution function

$D=$ treatment interaction dummy

$G()=$. treatment effect

$X_{i}=$ regressors for individual $i$.

The asymptotic variance of the estimated treatment effect is given by

$$
V(G(\theta))=\left[\frac{\partial G(\theta)}{\partial \theta}\right] V(\theta)\left[\frac{\partial G(\theta)}{\partial \theta}\right] /
$$

where $V(\theta)=$ asymptotic variance of $\theta$, or

$$
\begin{gathered}
\left.V(G(\theta))=\left[\frac{1}{N} \sum_{i}\left\{\varphi\left(X_{i} \theta \mid D=1\right) X_{i}\right)-\varphi\left(X_{i} \theta \mid D=0\right) X_{i}\right\}\right] V(\theta) \\
\left.\left[\frac{1}{N} \sum_{i}\left\{\varphi\left(X_{i} \theta \mid D=1\right) X_{i}\right)-\varphi\left(X_{i} \theta \mid D=0\right) X_{i}\right\}\right] /
\end{gathered}
$$

where $\phi=$ normal density function. Therefore, we calculate $\partial G(\theta) / \partial \theta$ for each female in the sample post 1986 and average over the sample. This mean is then pre and post multiplied by $V(\theta)$. 


\section{REFERENCES}

Alstott, Anne L., "The Earned Income Tax Credit and the Limitations of Tax-Based Welfare Reform." Harvard Law Review, 108(3), January 1995, pp. 533-592.

Bartik, Timothy J., Who benefits From State and Local Economic Development Policies?, Upjohn Institute for Employment Research, 1991.

Committee on Ways and Means, U.S. House of Representatives, Overview of Entitlement Programs (Green Book), Government Printing Office, July 7, 1993.

Committee on Ways and Means, U.S. House of Representatives, Overview of Entitlement Programs (Green Book), Government Printing Office, July 15, 1994.

Danziger, Sheldon, Robert Haveman and Robert Plotnick, "How Income Transfers Affect Work, Savings, and the Income Distribution: A Critical Review," Journal of Economic Literature, 19(3), September 1981, pp. 975-1028.

Dickert, Stacy, Scott Houser and John Karl Scholz, "The Earned Income Tax Credit and Transfer Programs: A Study of Labor Market and Program Participation," National Bureau of Economic Research Conference Report, Tax Policy and the Economy 1994.

Dickert, Stacy, Scott Houser, and John Karl Scholz, "Taxes and the Poor: A Microsimulation Study of Implicit and Explicit Taxes," National Tax Journal, 47(3), September 1994, pp. 621-638.

Edin, Kathryn and Christopher Jencks, "Reforming Welfare," in Christopher Jencks, Rethinking Social Policy: Race, Poverty and the Underclass, Harvard University Press, 1993.

Eissa, Nada, "Taxation and Labor Supply of Married Women: The Tax Reform Act of 1986 as a Natural Experiment," NBER Working Paper 5023, 1995.

Eissa, Nada and Jeffrey B. Liebman, "The End of Welfare as We Know It? Behavioral Responses to the Earned Income Tax Credit", Harvard University mimeo, 1993.

Fishman, Michael E. and Daniel H. Weinberg "The Role of Evaluation in State Reform Waiver Demonstrations" in Manski, Charles and Irwin Garfinkel, Evaluating Welfare and Training Programs. Harvard University Press, 1992.

Fraker, Thomas, Robert Moffitt, and Douglas Wolf, "Effective Tax Rates and Guarantees in the AFDC Program, 1967-1982," Journal of Human Resources, 20(2), Spring 1985, pp. 251-263.

Freeman, Richard B., "Employment and Earnings of disadvantaged Young Men in a Labor Shortage Economy, in Jencks, Christopher and Paul E. Peterson, eds., The Urban Underclass. Brookings Institution, 1991

General Accounting Office, Earned Income Tax Credit: Data on Noncompliance and Illegal Alien Recipients, October 1994. 
General Accounting Office, Earned Income Tax Credit: Design and Administration Could Be Improved, GGD-93-145, September 1993.

General Accounting Office, Earned Income Tax Credit: Advance Payment Option is Not Widely Known or Understood by the Public, GGD-92-26, February 1992.

Giannarelli, Linda, and Eugene Steuerle, "It's Not What You Make, It's What You Keep: Tax Rates Faced by AFDC Recipients," paper presented at the Association for Public Policy Analysis and Management Annual Research Conference, Chicago, October 25, 1994.

Greene, William H., Econometric Analysis, Macmillan Publishing Co, New York, 1990.

Hoffman, Saul D., and Laurence Seidman, The Earned Income Tax Credit: Antipoverty Effectiveness and Labor Market Effects, W.E. Upjohn Institute for Employment Research, 1990.

Holtzblatt, Janet, "Administering Refundable Tax Credits: Lessons from the EITC Experience," Proceedings of the National Tax Association-Tax Institute of America, 1991.

Holtzblatt, Janet, Janet McCubbin and Robert Gillette, "Promoting Work Through the EITC," mimeo, U.S. Department of the Treasury, June 4, 1994.

Liebman, Jeffrey B., "Noncompliance and the EITC," in progress 1995.

Moffitt, Robert, "Incentive Effects of the U.S. Welfare System," Journal of Economic Literature, 30(1), March 1992, pp. 1-61.

Mroz, Thomas A., "The Sensitivity of an Empirical Model of Married Women's Hours of Work to Economic and Statistical Assumptions," Econometrica, 55(4), July 1987, pp. 765-799.

Olson, Lynn M., and Audrey Davis, "The Earned Income Tax Credit:Views from the Street Level," WP Series, Center for Urban Affairs and Policy Research, Northwestern University, March 1994.

Scholz, John Karl, "The Participation Rate of the Earned Income Tax Credit," University of WisconsinMadison Institute for Research on Poverty Discussion Paper \#928-90, 1990.

Scholz, John Karl, "The Earned Income Tax Credit: Participation, Compliance and Antipoverty Effectiveness, National Tax Journal, 47(1), March 1994, pp. 63-87.

Slemrod, Joel, "Optimal Taxation and Optimal Tax Systems," Journal of Economics Perspectives, 4(1), Winter 1990, pp. 157-178.

Triest, Robert K., "The Effect of Income Taxation on Labor Supply in the United States," The Journal of Human Resources, 25(3), Summer 1990, 491-516.

Yelowitz, Aaron, "The Medicaid Notch, Labor Supply and Welfare Participation: Evidence from Eligibility Expansions," MIT mimeo, 1994. 
Zabel, Jeffrey E., "The Relationship Between Hours of Work and Labor Force Participation in Four Models of Labor Supply Behavior," Journal of Labor Economics, 1993. 
Figure 1

\section{EITC Budget Constraint}

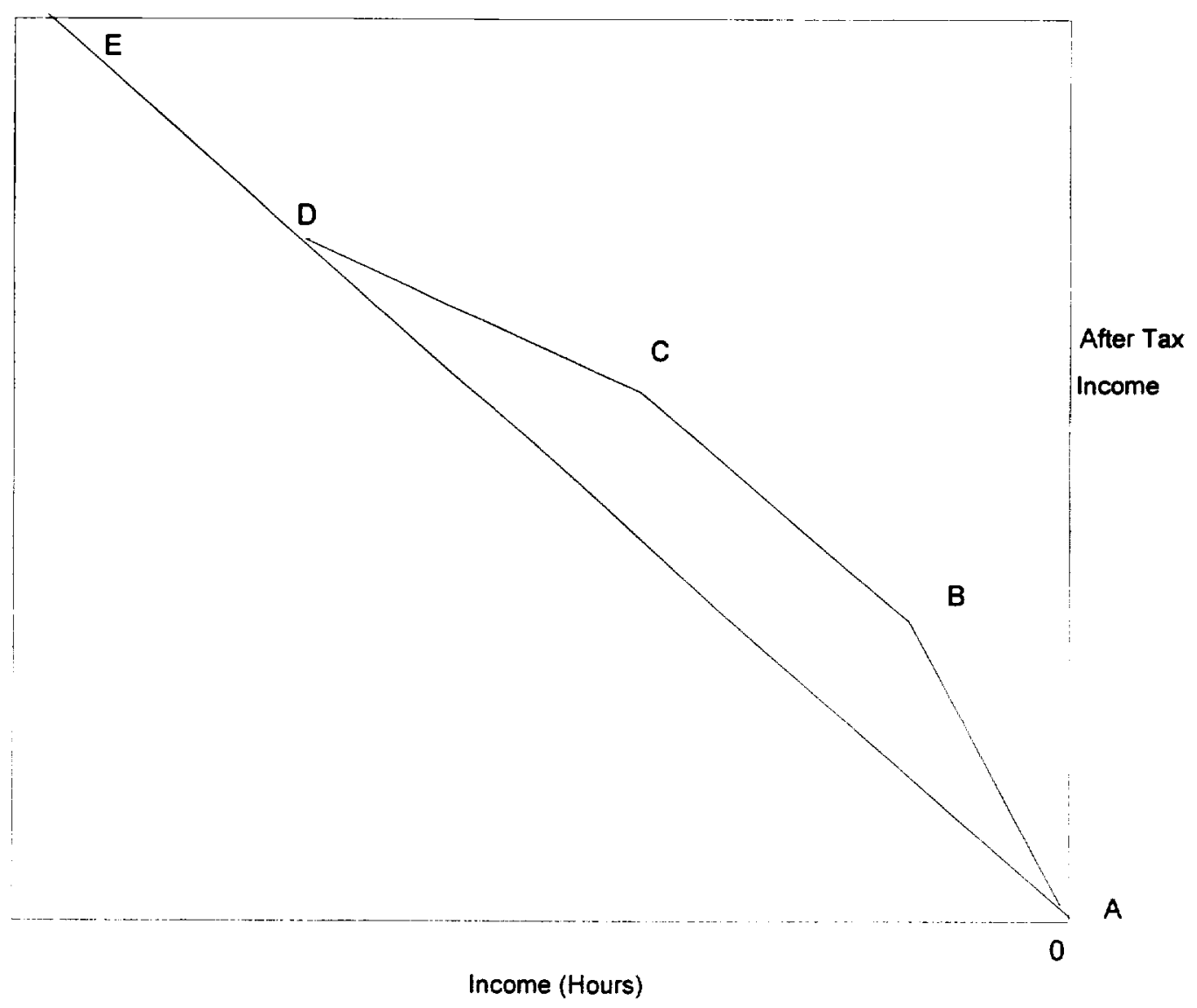


Figure 2

Labor Force Participation Rates, 1981 to 1992

Unmarried Females, Ages 16-44

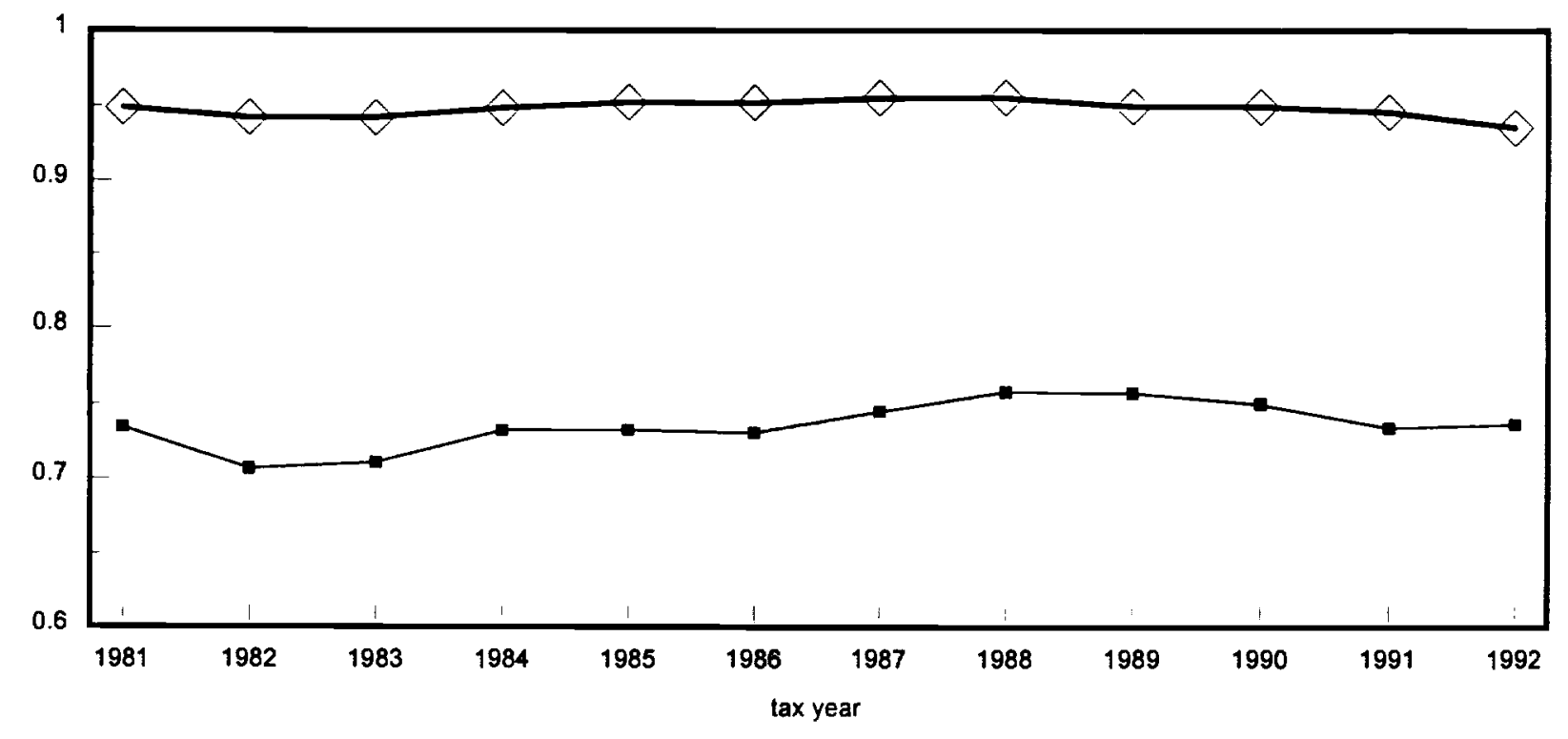

with children

without children

Source: authors' calculations from CPS.

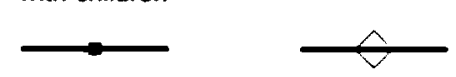




\section{Figure 3}

\section{Maximum EITC and Coefficients on KID*YEAR Dummies}

All Unmarried Females

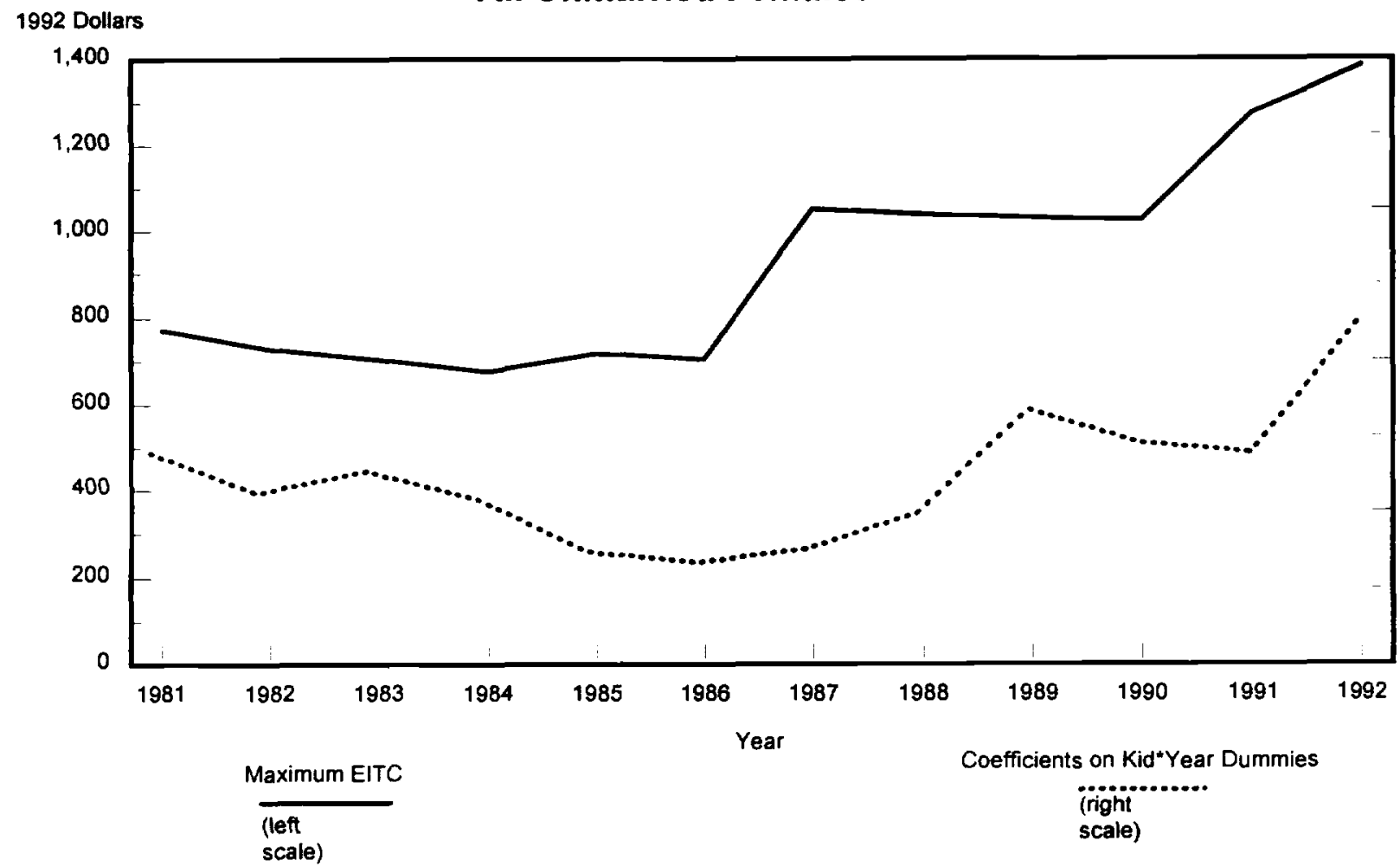


Figure 4

Maximum EITC, Unemployment Rate,

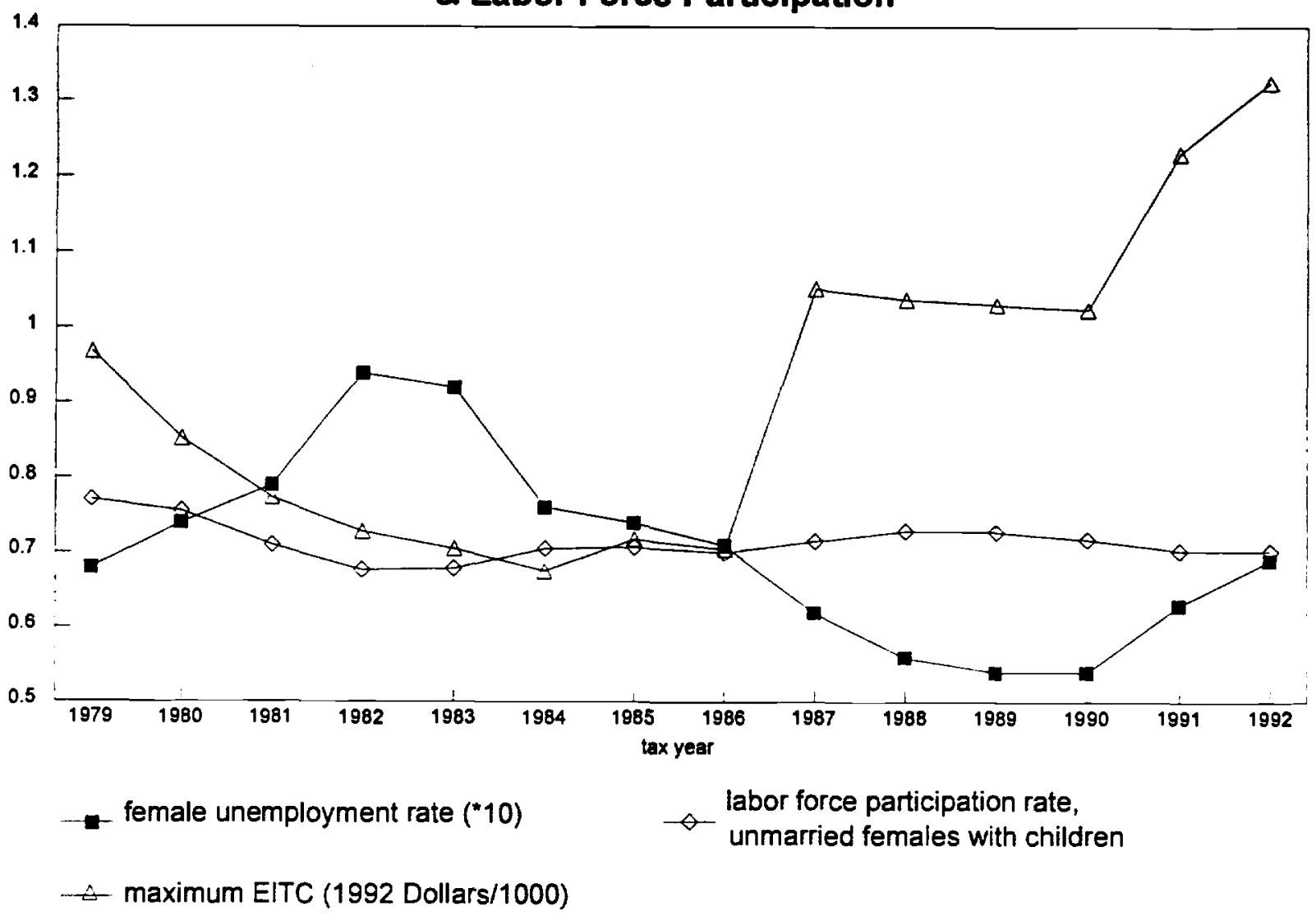

Sources: Authors' calculations from CPS. Council of Economic Advisors (1993).

and Committee on Ways and Means (1994). 
Figure 5

1986 and 1988 Earned Income Tax Credit

1992 Dollars

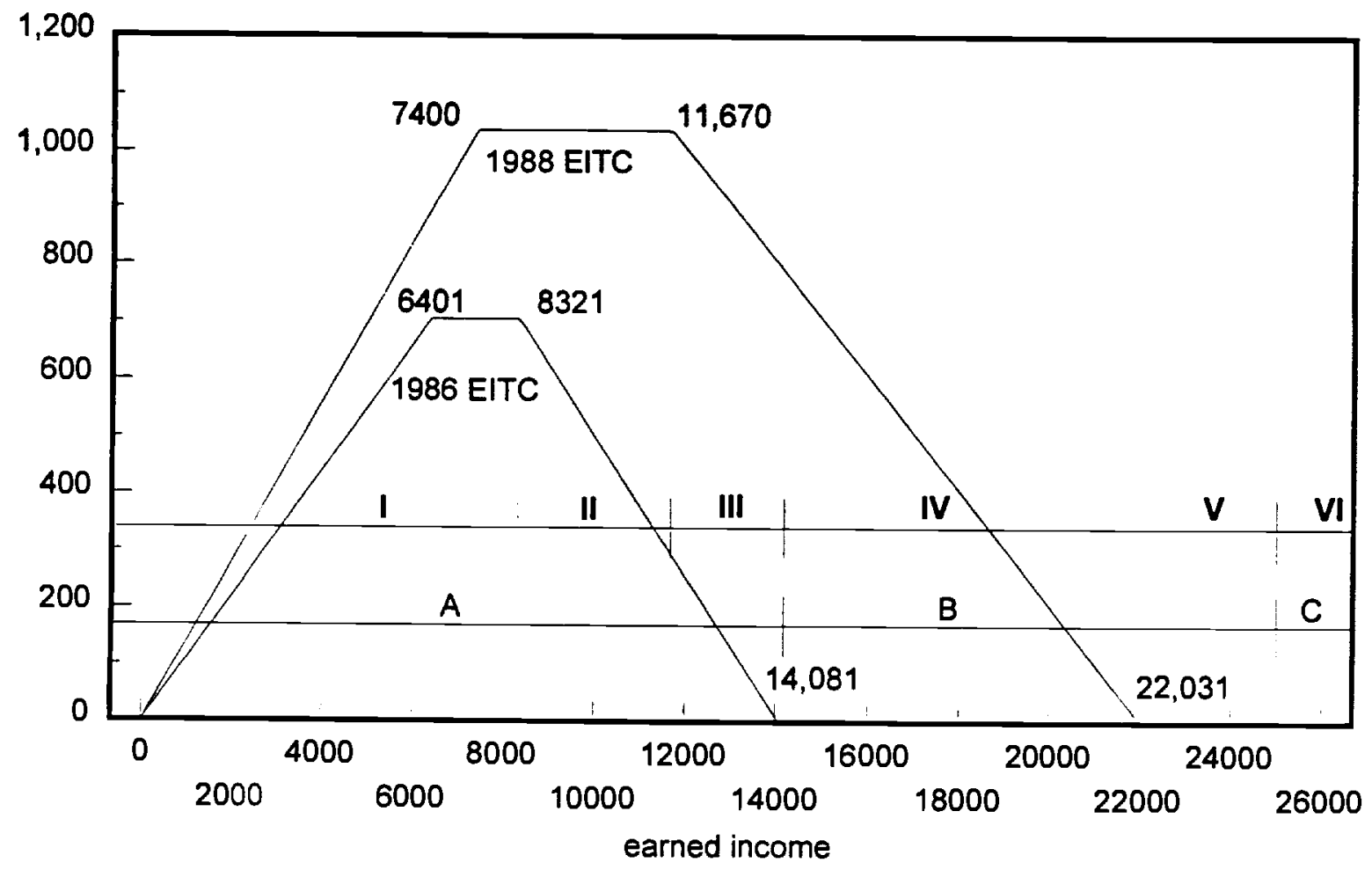


Figure 6

Increase in EITC and Relative Income Tax Reduction Between 1986 and 1988

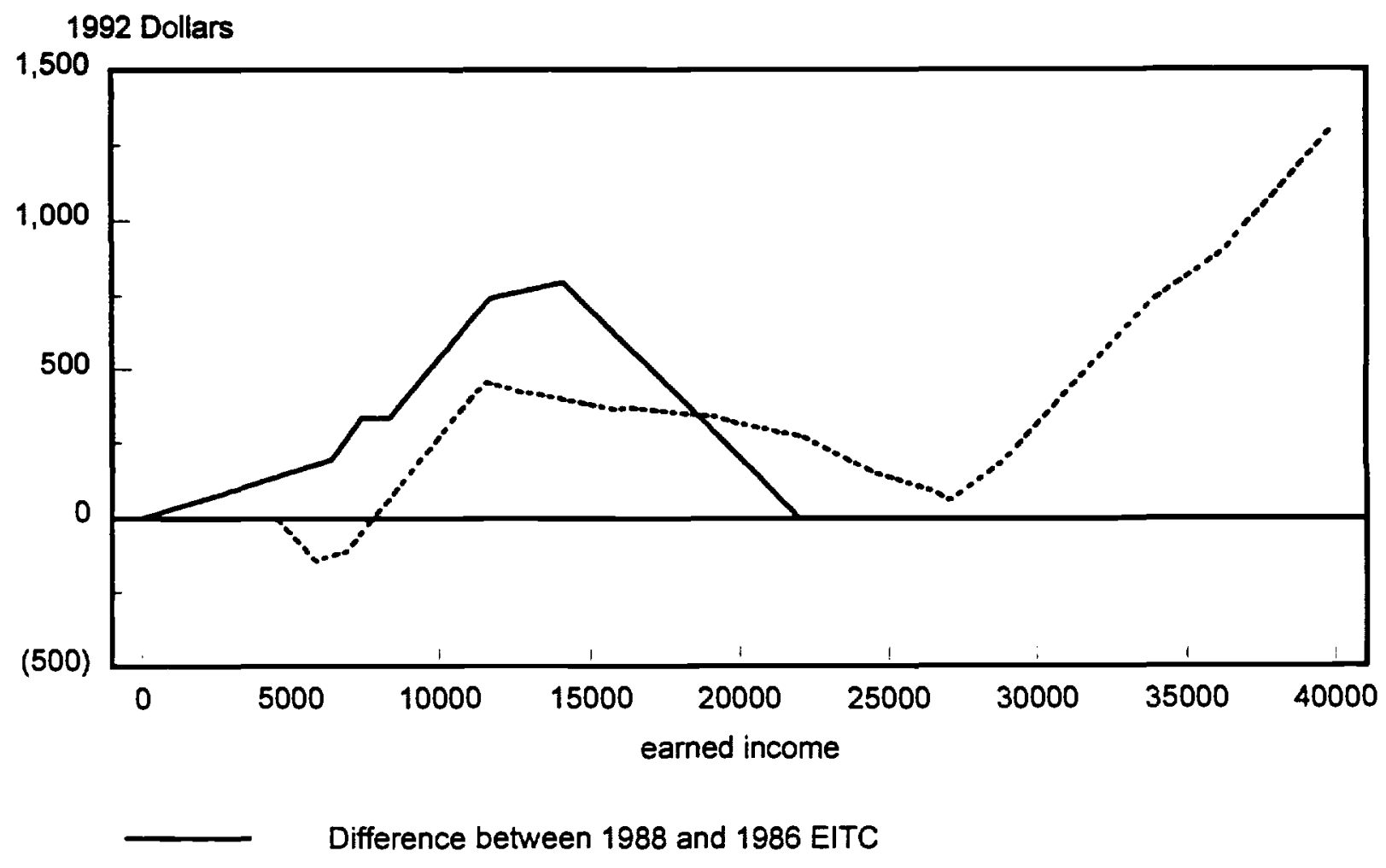

............. Household head reduction in taxes minus single filer reduction in taxes 